\title{
The rise of photoresponsive protein technologies applications in vivo: a spotlight on zebrafish developmental and cell
} biology [version 1; peer review: 2 approved]

Renee Wei-Yan Chow ${ }^{1-4}$, Julien Vermot (Di)1-4

${ }^{1}$ Institut de Génétique et de Biologie Moléculaire et Cellulaire, Illkirch, France

${ }^{2}$ Centre National de la Recherche Scientifique UMR8104, Illkirch, France

${ }^{3}$ Institut National de la Santé et de la Recherche Médicale, U964, Illkirch, France

4Université de Strasbourg, Illkirch, France

V1 First published: 11 Apr 2017, 6(F1000 Faculty Rev):459

https://doi.org/10.12688/f1000research.10617.1

Latest published: 11 Apr 2017, 6(F1000 Faculty Rev):459

https://doi.org/10.12688/f1000research.10617.1

\section{Abstract}

The zebrafish (Danio rerio) is a powerful vertebrate model to study cellular and developmental processes in vivo. The optical clarity and their amenability to genetic manipulation make zebrafish a model of choice when it comes to applying optical techniques involving genetically encoded photoresponsive protein technologies. In recent years, a number of fluorescent protein and optogenetic technologies have emerged that allow new ways to visualize, quantify, and perturb developmental dynamics. Here, we explain the principles of these new tools and describe some of their representative applications in zebrafish.

Keywords

embryogenesis, CRE , optogenetic technology, fluorescent proteins

\section{Open Peer Review \\ Approval Status

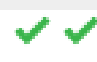 \\ 1 \\ 2 \\ version 1 \\ 11 Apr 2017 \\ Faculty Reviews are review articles written by the prestigious Members of Faculty Opinions. The articles are commissioned and peer reviewed before publication to ensure that the final, published version is comprehensive and accessible. The reviewers who approved the final version are listed with their names and affiliations. \\ 1. Filippo Del Bene, - Institut Curie, PSL Research University, INSERM U 934, CNRS UMR3215, Paris, France \\ 2. Periklis Pantazis, Eidgenössische Technische Hochschule (ETH) Zurich, Basel, Switzerland Manuel Alexander Mohr, Eidgenössische Technische Hochschule (ETH) Zurich, Basel, Switzerland}

Any comments on the article can be found at the end of the article. 
Corresponding author: Julien Vermot (julien.vermot@igbmc.fr)

Competing interests: The authors declare that they have no competing interests.

Grant information: JV and RC are supported by Fondation pour la Recherche Médicale (DEQ20140329553). JV is supported by the Agence Nationale de la Recherche (ANR) (ANR-15-CE13-0015-01 and ANR-12-ISV2-0001-01), the European Molecular Biology Organization Young Investigator Program, European Research Council consolidator grant Evalve (682938), and grant ANR-10-LABX-0030-INRT, a French State fund managed by the ANR under the frame program Investissements d'Avenir labeled ANR-10-IDEX-0002-02.

Copyright: ( 2017 Chow RWY and Vermot J. This is an open access article distributed under the terms of the Creative Commons Attribution License, which permits unrestricted use, distribution, and reproduction in any medium, provided the original work is properly cited. Data associated with the article are available under the terms of the Creative Commons Zero "No rights reserved" data waiver (CC0 1.0 Public domain dedication).

How to cite this article: Chow RWY and Vermot J. The rise of photoresponsive protein technologies applications in vivo: a spotlight on zebrafish developmental and cell biology [version 1; peer review: 2 approved] F1000Research 2017, 6(F1000 Faculty Rev):459 https://doi.org/10.12688/f1000research.10617.1

First published: 11 Apr 2017, 6(F1000 Faculty Rev):459 https://doi.org/10.12688/f1000research.10617.1 


\section{Introduction}

Since as early as the 1930 s, researchers in classic development and embryology have praised the ease of handling zebrafish embryos and their optical clarity ${ }^{1}$. These small tropical fishes are easy to house, produce large numbers of externally fertilized eggs (a pair of zebrafish can produce up to 300 fertilized eggs a week), and have relatively short generation times compared with other vertebrate models (around 3 months). They also develop rapidly: within a day of development, the embryonic axes are established, somitogenesis is complete and neural development is under way, and by five days post-fertilization, all major organs have formed and the larvae are able to swim freely and feed. Zebrafish embryos are transparent during the first day of development, allowing direct observation of their embryonic development. Although several types of pigment gradually restrict optical access to deeper structures as the embryos develop, pigmentation can be greatly reduced through the simple addition of chemical drugs (for example, 1-phenyl-2-thiourea, or $\mathrm{PTU}^{2}$ ) to the water. There are also a large number of pigmentation mutants that survive to adulthood. For example, nacre mutants lack skin melanophores ${ }^{3}$, sandy and albino mutants show melanin deficiency in both skin and the retinal pigmented epithelium, roy orbison and shady mutants lack skin iridophores ${ }^{4,5}$, and pfeffer/salz mutants have greatly reduced numbers of xanthophores ${ }^{6}$. Combinatorial pigmentation mutants, such as casper ${ }^{4}$, which carry both the roy orbison and nacre mutations, and crystal, which carry the nacre, roy orbison, and albino mutations, offer optical access to even adult fish without incurring the toxic effects of PTU.

The zebrafish rose to prominence as a model for developmental and cell biology in the mid-1990s, when two large-scale forward genetic screens were carried out ${ }^{8}$, and a detailed morphological characterization of zebrafish development was performed ${ }^{9}$. At the time, forward genetics was not technically or economically possible in other prominent vertebrate models, such as frog, chick, and mouse. Although reverse genetics in zebrafish was difficult, microinjection of early zebrafish embryos with either mRNA or antisense morpholino oligonucleotides could be used to transiently overexpress or knockdown gene function ${ }^{10,11}$.

By the time the large-scale forward genetic screens for zebrafish were complete, a wave of change had happened in the biological sciences because of improvements in fluorescence microscopy. The optical transparency and small size of the zebrafish embryo could be fully exploited, and zebrafish emerged as a powerful model to image cellular and subcellular developmental events in vivo. At first, zebrafish transparency was mainly used to generate fate maps during early embryo development ${ }^{12}$ and to image neurons of the nervous system ${ }^{13}$; cells were typically labeled by injection of fluorescent dyes, including fluorescent calcium indicator dyes. The optical transparency of the zebrafish also meant that it was possible to target specific populations of fluorescent neurons for laser ablation ${ }^{13}$. The development of green fluorescent protein (GFP) and its spectral variants as genetically encoded fluorescent labels made it possible to follow the movements, positions, and interactions of tagged proteins, organelles, and whole cells in a variety of tissues ${ }^{14,15}$. That zebrafish transgenic lines expressing genetically encoded fluorescent proteins could be made was first shown in $1995^{16,17}$. A few years later, a landmark multiphoton time-lapse imaging study found a way to specifically express GFP in the zebrafish vasculature ${ }^{18}$. This study revealed for the first time the dynamics of angiogenesis in both wild-type and mutant backgrounds and demonstrated the power of fluorescent protein technology when combined with the zebrafish model. When the Tol2 transposon system made zebrafish transgenesis efficient, a large number of transgenic lines expressing fluorescent proteins tagged to different proteins were made, allowing the labeling of various subcellular structures, cells, tissues, and organs ${ }^{19}$. The Tol2 system was later combined with the Gal4/UAS system to generate a large collection of fish lines that express Gal4 in specific cells, tissues, and organs ${ }^{20,21}$ - a collection that remains invaluable today.

The mid-2000s heralded the bloom of optogenetics: the use of light to manipulate cell activity using genetically encoded lightresponsive proteins. Until this point, the only form of optogenetics was the inactivation of proteins through chromophore-assisted light inactivation, where the chromophore was a fluorescent protein, such as enhanced GFP (EGFP) ${ }^{22}$. However, our ideas regarding the scope of photoresponsive protein-based tools changed dramatically when a pioneering study showed that, by introducing the gene for channelrhodopsin-2 (a microbial opsin) into cultured mammalian neurons, one could trigger neuronal depolarization using light ${ }^{23}$. Whereas performing optogenetic experiments on mouse neurons in vivo required invasive surgery, delivering light to zebrafish neurons was relatively straightforward and the zebrafish's small size meant that all neurons from a defined circuit can be monitored at once under a laser scanning microscope. The zebrafish thus played a large part in the "optogenetic revolution" that occurred in the neurosciences, which allowed experimentalists to functionally test the role of identified neurons in specific behaviors for the first time (reviewed in 24-27). To a limited extent, optogenetic use of membranebound opsins that are light-sensitive ion channels, pumps, or $\mathrm{G}$ protein-coupled receptors expanded from neuroscience into other fields of biology. Two notable uses of optogenetics in the zebrafish involved the expression of the light-gated pump halorhodopsin and the light-sensitive cation channel channelrhodopsin-2 in zebrafish cardiomyocytes, allowing the study of the formation of the cardiac pacemaker in the developing heart ${ }^{28}$ and the study of flow propagation in the embryonic vascular network ${ }^{29}$.

Over the years, the variety of fluorescent proteins has greatly expanded, and they now encompass a broad range of tools that go beyond simple labeling of biological structures. Although optogenetics still is most commonly associated with light-sensitive membrane-bound opsins for the study of neuronal function, recently there has been a proliferation of a new set of optogenetic tools based on light-dependent protein-protein interactions that promise to have broad application to all aspects of developmental biology. In this review, we discuss the advantages and 
weaknesses of some of the latest developments in fluorescent protein and optogenetic technologies and focus specifically on their use in zebrafish.

\section{Innovative fluorescent protein technologies \\ Color coding cells}

One major challenge in developmental biology is to visualize cellular organization in complex tissues; a related challenge is to follow changes in cell morphology and movement over time and to perform lineage tracing and understand the origin of cells and cell populations. Driving fluorescent proteins under certain promoters can restrict fluorescent protein expression to specific cell subpopulations, but the labeling is often too dense to achieve single-cell resolution when one is studying complex tissues, and sometimes there are no available promoters that are specifically expressed in the cells of interest. A decade ago, researchers came up with a cell-labeling technique to distinguish individual neurons in the mouse brain. The technique, called Brainbow, uses stochastic Cre-loxP recombination to express one of several spectrally distinct fluorescent proteins from a single transgene. Since multiple cassettes are integrated at a single genomic site, and the choice within each cassette is made independently, varied combinations of the different fluorescent proteins label individual cells with distinct fluorescent profiles and generate what is effectively a multicolored Golgi stain ${ }^{30}$. Brainbow constructs were first tested in zebrafish in $2011^{31}$, and several transgenic lines incorporating Brainbow technology, including the Zebrabow series ${ }^{32}$ and $\operatorname{Tg}$ (UAS:brainbow) ${ }^{33}$, soon followed (Table 1). The Brainbow strategy has been adopted for cell tracking in several zebrafish tissues to great success. For example, Brainbow technology allowed clonal analysis of the zebrafish heart and revealed how the orchestrated division of cardiomyocytes results in the distinct architectures of the ventricle and atrium ${ }^{34,35}$ and how endocardial cell movements contribute to cardiac valve formation ${ }^{36}$. It also allowed the identification and quantification of collective cell behaviors, enabling zebrafish skin homeostatic maintenance and response to injury ${ }^{37}$ and the precise manner by which zebrafish retinal ganglion cell axons laminate in the tectum ${ }^{33}$.

In the original Brainbow design, the expression levels of fluorescent proteins do not follow an even distribution, thus reducing the randomness of fluorescent protein expression and increasing the

\section{Table 1. Brainbow-related zebrafish transgenic lines.}

\begin{tabular}{|l|l|}
\hline Line & References \\
\hline Tg(ßactin2-Brainbow) & $34,35,37$ \\
\hline Tg(ubi-Zebrabow-S) & 32 \\
\hline Tg(ubi-Zebrabow-M) & 32 \\
\hline Tg(UAS:Brainbow) & 33 \\
\hline $\operatorname{Tg}($ UAS:Zebrabow-V) & 32 \\
\hline Tg(UAS:Zebrabow-B) & 32 \\
\hline Tg(actb2:multibow) & 38 \\
\hline
\end{tabular}

likelihood that neighboring cells express indistinguishable spectral profiles. Other disadvantages include not only the possibility of changing the color code of the cell because of permanent CRE expression but also the sensitivity of the technique to factors that affect fluorescent protein signal intensity, such as promoter activity, cell depth, or autofluorescence. Recently, there have been efforts to overcome these problems by using independent transgenes for each fluorescent protein, each equipped with a binary ON/OFF switch. In this approach, called Multibow, fluorescent proteins are initially OFF and then probabilistically ON or OFF following Cre recombination ${ }^{38}$. A zebrafish line generated using this technique takes advantage of our increasing repertoire of fluorescent proteins, expressing no fewer than seven different fluorescent proteins, which have been tagged to three different subcellular localizations (membrane, cytoplasm, and nucleus) to increase variation of labeling ${ }^{38}$. Although Multibow has not been used for any biological applications yet, it is an interesting new addition to the multicolor labeling toolbox. Given that membrane, cytoplasmic, and nuclear compartments show large variations in fluorescent protein signal intensity, it can be difficult to distinguish the color of one or more of these compartments ${ }^{38}$. For example, in some cases, the nucleus of the cell is much more brightly labeled than the cytoplasm or membrane, making it difficult to visualize cellular morphology ${ }^{38}$. Nonetheless, Multibow may prove useful, especially for cell lineage studies where the use of time-lapse imaging is not possible.

A caveat of current multicolor labeling technologies for live embryo imaging is the necessity to image embryos multiple times, including using violet light for the excitation of blue fluorescent proteins, which can cause phototoxicity. This problem is partially elevated by improved microscopy techniques that require fewer excitation photons to achieve the same resolution. A particularly notable milestone in recent years is the adaptation of light-sheet microscopy for the imaging of live embryos ${ }^{39,40}$. Light-sheet imaging combines high imaging speed with low light exposure, which, when combined with the optical transparency of zebrafish and standard fluorescent protein labeling techniques, enables many developmental processes to be imaged at unprecedented spatial and temporal resolution. Also significant is the introduction of new point-scanning microscopy setups that apply wavelength mixing to provide simultaneous, efficient, and independent two-photon excitation of more than two spectrally distinct fluorophores, thereby avoiding the use of shorter, more phototoxic wavelengths ${ }^{41}$. Another deterrent to using Brainbow technology for cell lineage tracing studies is the time lag between when CRE is first delivered/expressed and when fluorescent proteins mature. An alternative strategy that does not have this limitation is to follow optically highlighted cells, as discussed in the section below.

\section{Highlighting single cells with light}

Photoconvertible fluorescent proteins change emission wavelengths in response to irradiation with light of a particular wavelength, whereas photoactivatable fluorescent proteins gain fluorescence after irradiation of light of a particular wavelength (Table 2). Together, these proteins serve as optical highlighters, 


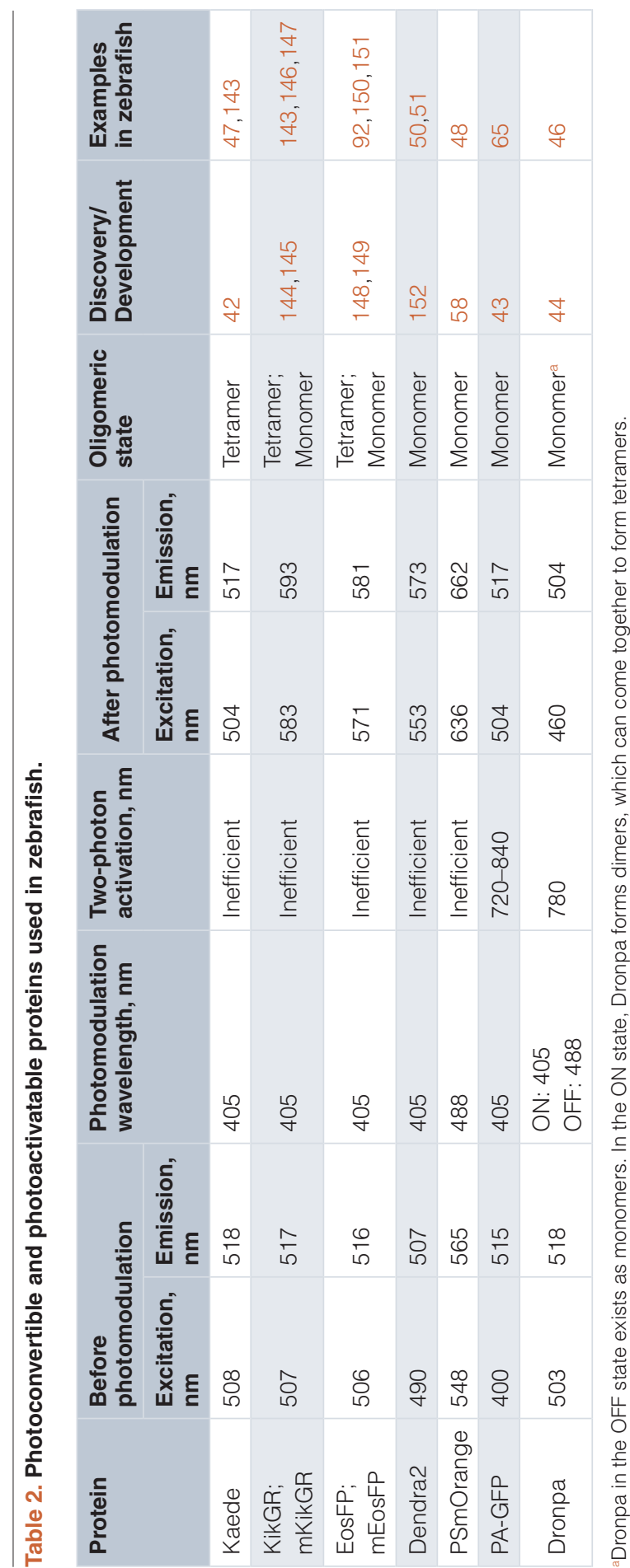


allowing the rapid and precise labeling of biological structures using laser light. The first fluorescent proteins advertised as being photoconvertible and photoactivatable were Kaede and photoactivatable GFP (PA-GFP), respectively. Kaede's photoconvertible properties were discovered serendipitously when the researchers left a vial of the protein overnight by the window and discovered the next day that sunlight had converted the sample from green to red; Kaede is named after the leaves of the Japanese maple that change from green to red in the autumn. Further investigation revealed that the red form of Kaede reflects the protein's ionized state and that this change in emission wavelength can be effectively and irreversibly induced by illuminating the protein with violet 405-nm light ${ }^{42}$. By contrast, PA-GFP was created purposely by modifying the structure of GFP through mutagenesis so that the protein would greatly increase its fluorescence after irradiation using violet $405-\mathrm{nm}_{\text {light }}{ }^{43}$. A few years after the introduction of Kaede and PA-GFP, Dronpa, a fluorescent protein that was not only photoactivatable but photoswitchable, was discovered. The fluorescence of this interesting protein can be switched off by blue 488-nm light and switched on again by violet 405-nm light exposure $^{44}$. Since then, a number of new optical highlighters have been developed, and significant effort has been made to create monomeric versions that perform better in protein fusion studies (reviewed in 45). Optical highlighters have been used in zebrafish to visualize single-cell morphology ${ }^{46,47}$; to track cells for cell lineage, migration, or proliferation analyse ${ }^{48-52}$; and to mark cells for laser ablation $^{53}$ (Table 2).

Recently, there have been two exciting developments relating to photoconvertible proteins. The first development is the surprising discovery that the green-to-red photoconvertible protein Dendra2 can be "primed converted". It turns out that rather than using violet light, one can photoconvert Dendra2 by irradiating the protein first with blue light and then with near-infrared light ${ }^{54}$. The mechanism responsible for this unusual phenomenon is still unknown, but its usefulness soon became evident. Firstly, infrared light and blue light are less toxic than violet light and penetrate deeper into tissue. Secondly, the dual wavelength mechanism overcomes one of the caveats of green-to-red photoconvertible proteins: they cannot be efficiently photoconverted using multiphoton illumination ${ }^{55,56}$. Whereas one-photon illumination is not confined in the axial direction (Figure 1A), primed conversion (Figure 1B, 1C) can spatially confine the photoconverted region in all three dimensions by allowing both the priming and the converting beam to meet only at a small axially confined focal volume $^{56}$. Importantly, primed conversion requires much lower peak power than two-photon photomodulation to accomplish confinement ${ }^{56}$. The effectiveness of this technique was demonstrated by highlighting neuronal morphology at single-cell resolution in the densely labeled zebrafish brain ${ }^{56}$. Primed conversion of Dendra2 was also shown to be possible using light from red lasers instead of the more uncommon and expensive near-infrared lasers, albeit at much lower efficiencies ${ }^{57}$. Given that many transgenic lines expressing Dendra2-including PhOTO zebrafish (photoconvertible optical tracking of zebrafish) lines that ubiquitously label nuclear or plasma membrane proteins using Dendra $2^{51}$ - are readily available, primed conversion promises to be a useful technique for future studies.

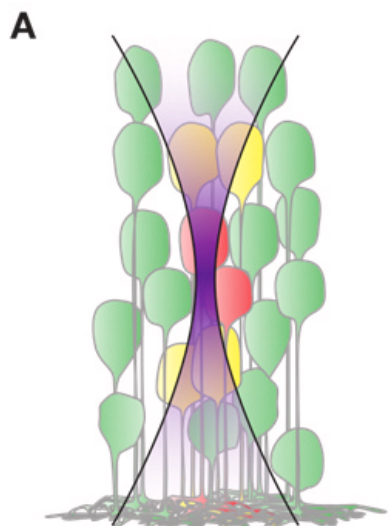

Traditional

Photoconversion

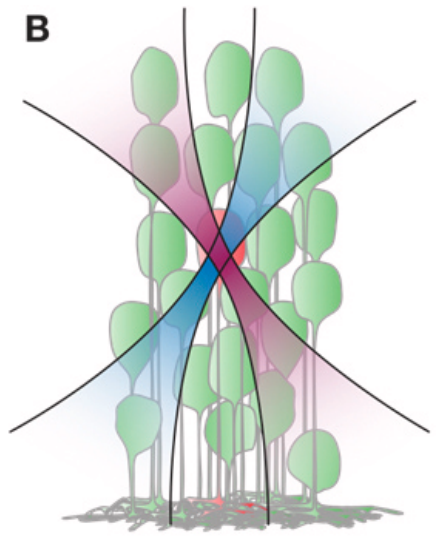

Primed Conversion

\section{C}

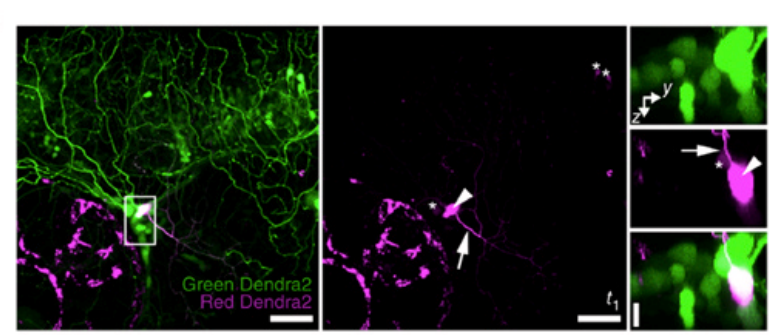

Figure 1. Primed photoconversion. (A) Traditional photoconversion experiments use green-to-red photoconvertible proteins that change from emission after being converted with violet 405-nm light. It is often difficult to specifically photoconvert single cells because the laser beam is not confined in the axial direction. (B) Primed conversion involves first priming green-to-red photoconvertible proteins with blue 488-nm light, before converting the protein with near infra-red 730-nm light. Hence, only cells at the intersection of the two laser beams are photoconverted. (C) Left and middle: Primed photoconversion of Dendra2 in a single neuron in the trigeminal ganglion of a zebrafish at 3 days post-fertilization (maximum-intensity projection of about $82 \mu \mathrm{m}$ in depth). Right: Higher-magnification axial orientation images of the boxed region in the left frame. Arrowhead indicates the photoconverted cell, and the arrow indicates a neurite extending from the cell body. Asterisks indicate cells that had noticeable signal in the red Dendra2 channel even before photoconversion. Reprinted with permission from Macmillan Publishers Ltd ${ }^{56}$.

The second development is the long-awaited arrival of new photoconvertible proteins with red-shifted excitation and emission wavelengths, such as PSmOrange and its improved version PSmOrange $2^{58,59}$. These proteins have many advantages over traditional green-to-red fluorescent proteins, not the least of which is that they can be easily used in conjunction with the many available zebrafish lines that already use the green emission wavelength to label biological structures. Another advantage is that the blue-green light needed for one-photon excitation of the protein is less toxic to cells than violet light. One study suggests that PSmOrange 2 can also be efficiently photoconverted using infrared light from a two-photon laser $^{59}$, raising the possibility of spatially confined conversion in tissues using two-photon laser light, although this study was performed in cell culture and the two-photon conversion of PSmOrange2 in vivo remains to be 
verified. Although PSmOrange2 has not been tested in zebrafish, one study reported the injection of H2B-PSmOrange mRNA into one-cell stage zebrafish embryos to track photoconverted cells during ventral habenulae development ${ }^{48}$. Given the study's success, we expect PSmOrange and its variants to be much more widely used in the future.

In addition to classic uses of optical highlighters, we expect great applications of single-cell photoconversion and photoactivation in the field of gene expression profiling with the recent development of single-cell genomics. Recent experiments prove its feasibility in vivo ${ }^{60}$ and promise important discoveries in the field of molecular cellular identity and clonal analysis.

\section{Genetically encoded calcium indicators}

Genetically encoded calcium indicators (GECIs) have become essential tools to study calcium signaling in a cell type- or cell compartment-specific manner. Since calcium is a second messenger for neurotransmitter reception and membrane depolarization in neurons, GECIs have been especially useful in the study of neuronal function. Most GECIs fall into one of two main groups: Förster resonance energy transfer (FRET)-based indicators, which are composed of two fluorescent proteins linked by a $\mathrm{Ca}^{2+}$ responsive element, such as the cameleons, and those based on a single circularly permutated fluorescent protein and a $\mathrm{Ca}^{2+}$ responsive element, such as the GCaMPs. Improving the performance of these GECIs has sustained research interest over the last 17 years, and at present the state-of-the-art GCaMP6 series outstrip the performance of the most commonly used synthetic calcium dyes ${ }^{61-63}$. Expressed in cultured neurons, the GECIs now possess the sensitivity and kinetics fast enough to detect single action potentials as well as peak fluorescence intensity levels comparable to that of the parental circularly permuted EGFP itself $^{61}$.

Zebrafish was the first vertebrate model system where GECI expression was used to visualize neuronal activity in vivo ${ }^{64}$. Today, the use of GECIs has been combined with light-sheet microscopy to visualize neuronal activity in the entire zebrafish brain $^{7,65-69}$. Our ability to visualize neuronal activity in whole zebrafish brains has improved dramatically with the arrival of new light-sheet microscope technology, most notably IsoView microscopy ${ }^{68}$, which generates images of greater spatial resolution by performing fluorescence detection along four orthogonal directions, and two-photon light-sheet microscopy ${ }^{69}$, which uses light of wavelength greater than that in the visible spectrum to stimulate GECIs and thus has greater tissue penetration and prevents unwanted visually evoked neuronal activity during imaging. Also significant is the introduction of a new zebrafish pigmentation triple mutant, crystal, that allows unprecedented optical access to the retina and the brain ${ }^{7}$.

Beyond studying neuronal function, GECI expression in zebrafish has been instrumental in studying the diverse roles of calcium signaling during development, particularly during cardiovascular development. For example, GECIs were used to identify and analyze stages of cardiac conduction that correspond to cellular and anatomical changes of the developing zebrafish heart and, in combination with a forward genetic screen, to identify conduction-specific mutations ${ }^{70}$. Recently, GECIs were used to characterize heart conduction defects in a zebrafish model of desminopathy, a type of muscle disorder ${ }^{71}$, and to show that calcium signaling is critically involved in cilia-mediated blood flow sensing ${ }^{72}$ and sprouting angiogenesis ${ }^{73}$ in endothelial cells during early vascular morphogenesis.

Excitingly, the combined improvements in GECI brightness and microscopy have opened up the possibility to study calcium signaling in a cell compartment-specific manner in live zebrafish embryos. For example, SyGCaMP2, a synaptic vesicle calcium reporter that consists of GCaMP2 fused to synaptophysin, has allowed both the identification of synapse localization and the reporting of electrical activity in the zebrafish optic tectum and retina $^{74}$; migrating zebrafish neutrophils have been shown to display enriched leading-edge calcium flux, a finding in contrast to ex vivo studies ${ }^{75}$; zebrafish myocytes were found to show sustained increase in mitochondrial calcium levels during spontaneous muscle contraction ${ }^{76}$; and calcium oscillations within cilia were found to be required for asymmetric Nodal signaling in the zebrafish left-right organizer during left-right symmetry breaking 77 .

Another exciting development is the introduction of red GECIs, which facilitate experiments that require dual-color imaging $^{78-81}$. The latest red GECIs-jRCaMP1a, $\mathrm{b}^{78}, \mathrm{jRGECO} 1 \mathrm{a}^{78}$, and R-CaMP2 ${ }^{79}$ - approach the performance of GCaMP6. The makers of jRCaMP1a,b and jRGECO1a tested the performance of six red GECIs in zebrafish, and their results suggest that jRGECO1a shows the greatest sensitivity in the animal but that jRCaMP1b shows the fastest on- and off-kinetics ${ }^{78}$. The authors also advised that $\mathrm{jRCaMP} 1 \mathrm{~b}$ may be more suited to many optogenetic experiments than jRGECO1a since it does not photoswitch in response to blue light $^{78}$.

With the advancement in photoactivatable and photoconvertible protein technology (see earlier section), photoactivatable and photoconvertible GECIs are now also available, allowing optical selection of cells/cell compartments for calcium imaging $^{82-85}$. A particularly interesting photoconvertible GECI, called CaMPARI (calcium-modulated photoactivatable ratiometric integrator), undergoes efficient green-to-red photoconversion by violet 405-nm light when calcium levels are high ${ }^{86}$ (Figure 2A). Although both red and green forms of CaMPARI respond dynamically to calcium in a manner similar to other GECIs, its uniqueness lies in its ability to retroactively report calcium activity over defined periods of time. For example, by illuminating brains expressing CaMPARI for a few hours with violet 405-nm light, neurons that experience higher levels of activity become red fluorescent while neurons with low levels of activity remain green fluorescent. The permanent labeling alleviates the need to image the right cells at the right time to observe neuronal activity. The expression of CaMPARI in zebrafish has allowed the visualization of integrated neuronal activity in zebrafish subjected to different conditions - anesthetized, swimming freely, treated with seizure-inducing compounds, or put in extreme heat or cold (Figure 2B) - and the technique promises a number of potential uses, ranging from functional connectomics to transcriptional profiling based on cellular calcium signaling levels. 
A

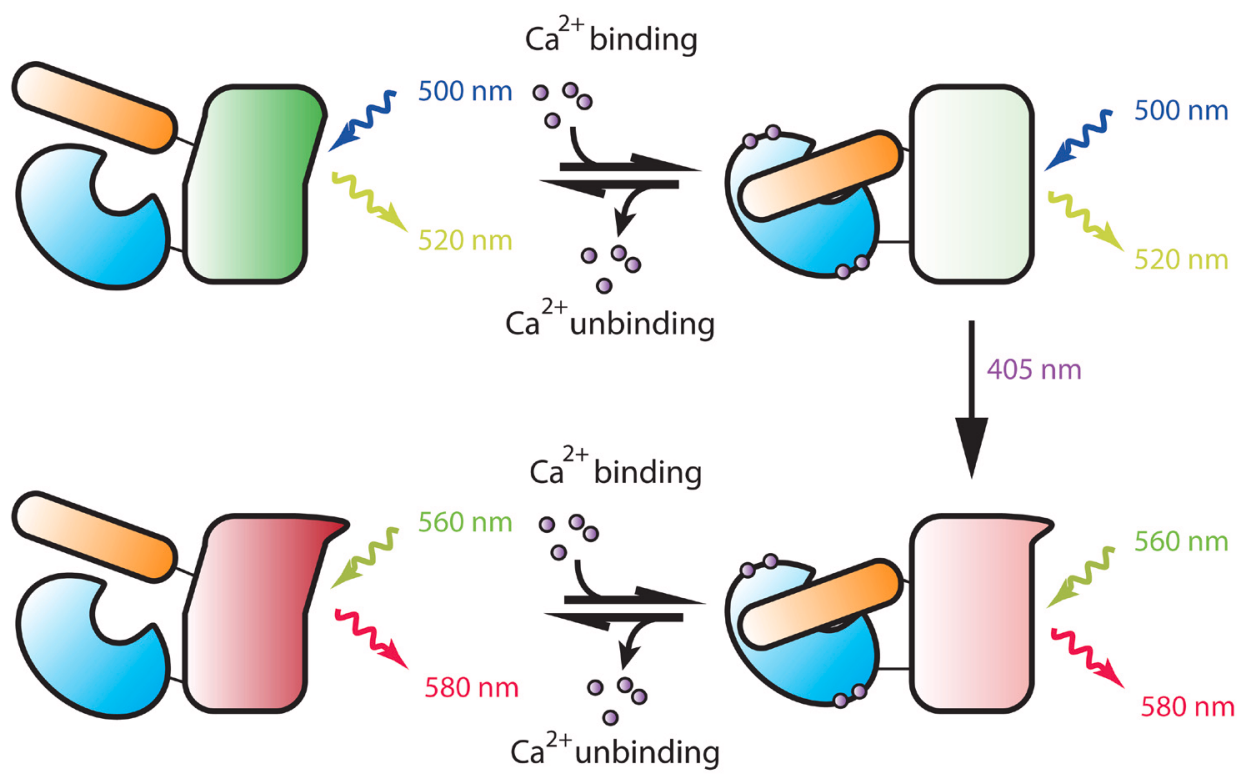

B
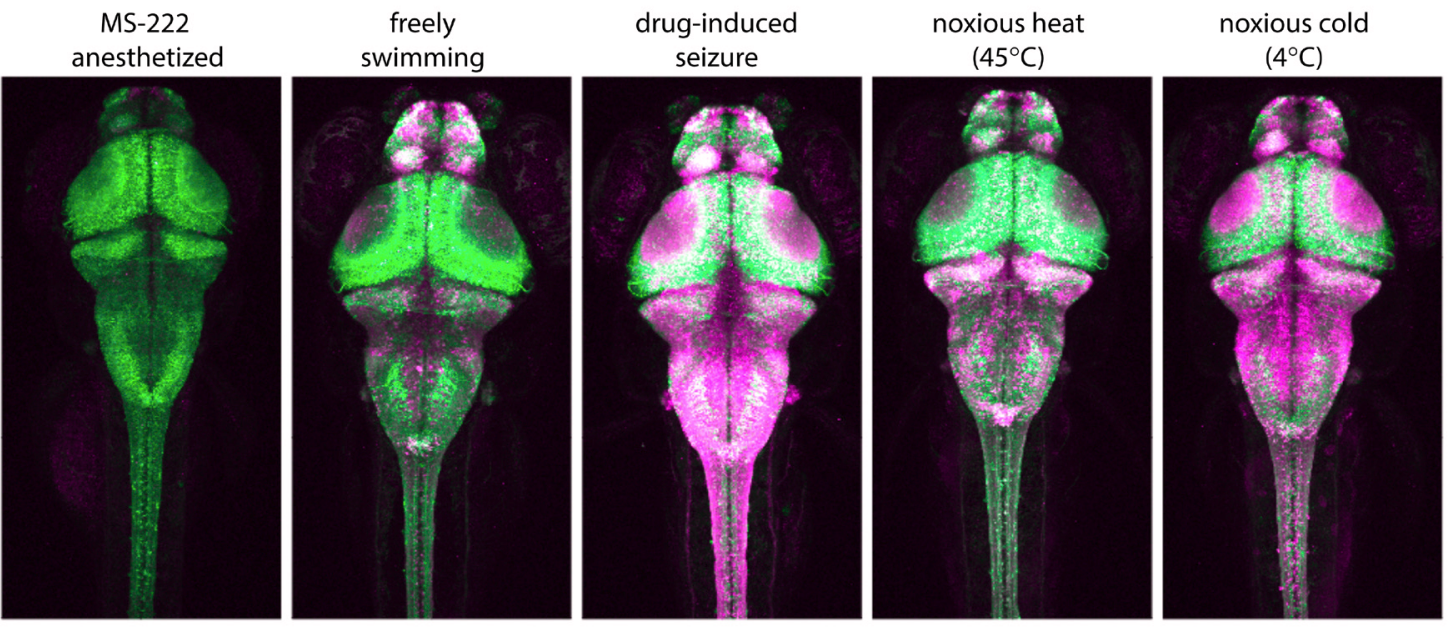

Figure 2. Calcium-modulated photoactivatable ratiometric integrator (CaMPARI). (A) Schematic of CaMPARI function. Both green and red forms of CaMPARI decrease fluorescence in the presence of calcium. CaMPARI is more susceptible to photoconversion by violet 405-nm light when intracellular calcium levels are high and this is most likely due to conformational change of the protein when bound to calcium. (B) Zebrafish larvae after 10 seconds of 405-nm light applied during exposure to different conditions. Each image represents a maximumintensity Z-projection of CaMPARI signal in a confocal stack through a 4- to 5-days post-fertilization larval zebrafish brain expressing CaMPARI pan-neuronally under the elavl3 promoter. Reprinted with permission from the American Association for the Advancement of Science ${ }^{86}$.

\section{Protein timers}

Traditional molecular biology and biochemistry have provided us with the identity of key proteins and regulatory networks involved in many developmental processes. However, the spatiotemporal dynamics of their regulation remains poorly understood, and imaging the proteome in vivo remains a significant challenge. Methods that have been used to monitor the behavior of proteins in zebrafish embryos include fluorescence recovery after photobleaching (FRAP) and its related technologies (fluorescence loss in photobleaching, fluorescence loss after photoactivation, and fluorescence localization after photobleaching $)^{87-93}$ and fluorescence correlation spectroscopy ${ }^{91,94-98}$. Recently, a new method has been developed to image protein turnover, based on the use of tandem fluorescent protein timers (tFTs) that change their emission wavelengths as the protein ages ${ }^{99}$.

Using fluorescent proteins that change emission wavelength as the protein ages itself is not a new idea. However, previous versions of fluorescent protein timers consist of a single fluorescent protein that switches color over time as its fluorophore undergoes successive chemical reactions ${ }^{100-102}$. These protein timers have low brightness and a tendency to form oligomers, which perturbs the 
behavior of the tagged proteins, and to our knowledge have not been used for in vivo studies. In this context, Knop et al. created a new type of fluorescent protein timer, the tFT, which involves a tandem fusion of a fast maturing protein of one color and a slower maturing protein of another color ${ }^{103}$. The idea is that by measuring the ratio of one color to the other, one could track protein movement within the cell; by using mathematical models that incorporate the known maturation kinetics of the fluorescent proteins, one could infer the protein turnover rate constants.

The first study featuring tFTs fused superfolder GFP (sfGFP), which reaches its peak intensity very quickly, with mCherry, which matures more slowly and reaches its peak intensity a few hours later. This tFT was then used to uncover the stable nature and asymmetric inheritance of nuclear pore complexes and identify regulators of $\mathrm{N}$-end rule-mediated protein degradation in yeast ${ }^{103}$. tFTs were introduced to the zebrafish model via two elegant studies investigating the dynamics of chemokines and cell-cell adhesion in the zebrafish lateral line primordium. In the first study, the authors tagged Cxcr4b, the receptor of chemokine Cxc112a, with sfGFP and the slower-maturing fluorescent protein TagRFP. The red/green fluorescence ratio at the plasma membrane was used as an indicator of the age of receptor populations, and the rate of ligand-triggered internalization was used to measure Cxc112a chemokine levels. By doing so, the authors effectively showed that a group of cells migrating collectively can self-generate gradients of chemokine activity across its length via polarized receptor-mediated internalization ${ }^{104}$. This study has established that tFTs can be sensitive, reliable tools for visualizing protein dynamics over many hours in live zebrafish embryos. Application of protein timers is broad, and other than the zebrafish line primordium ${ }^{104-106}$, protein timers have been used to study protein relocalization and stabilization during cardiac development ${ }^{107}$ and somite morphogenesis ${ }^{108}$.

It must be emphasized that tFTs are not neutral tags, and careful selection of fluorophores for use in tFTs has to be tailored to the expected turnover kinetics of the endogenous protein of interest. Given the wide range of fluorescent proteins with different spectral properties, and different maturation and degradation kinetics available, choosing the best combination of fluorescent proteins may be daunting. Recently, a study compared the performance of different GFPs within tFTs in yeast and provided comprehensive advice on the effects of the stability of the GFP fold on tFT behavior $^{109}$. Mathematical models of timer kinetics have been developed and were verified by applying a set of timers to once again investigate chemokine signaling gradients across the zebrafish posterior lateral line primordium. Interestingly, one of their findings was that FRET between the fast- and slow-maturing fluorophores increases timer signal, a point that may be useful for future timer designs. An interactive web application based on the models, called TimerQuant, has been made freely available to guide experimentalists on which fluorescent proteins to choose, to interpret timer readouts, and to detect differences in protein half-life ${ }^{110}$.

The relative ease of use of tFTs compared with fluorescence correlation spectroscopy and FRAP-based methods-including the ability to capture temporal information in a single snapshot, the possibility to perform experiments with relatively simple microscopy setups, and the availability of open source software-will likely mean that tFTs will become much more widely used in the future.

\section{Protease activity reporters}

Proteases are enzymes that perform hydrolysis of peptide bonds and are important in many biological and developmental processes through their ability to activate or inactivate their target proteins. Biosensors for monitoring protease activity typically involve a peptide specific for the protease of interest flanked by a pair of fluorescent proteins that undergo FRET. When the peptide is cleaved, the two fluorescent proteins separate and the FRET signal disappears. However, the signal of FRET reporters is weak because of small fluorescence change in the donor and acceptor fluorophores and the use of these reporters in vivo is limited.

Recently, Shu et al. introduced ZipGFP, a GFP-based protease reporter that achieves about 10 -fold fluorescence increase upon caspase activation ${ }^{111}$. To create ZipGFP, the researchers exploited the fact that GFP can be split into two fragments that have sufficient affinity to self-reassemble and form the complete, fluorescent $\beta$-barrel protein ${ }^{112}$ : the two parts of GFP were each flanked with heterodimerizing coiled coils, which prevent the two parts from self-assembling; the consensus protease cleavage sequence for caspase-3 was incorporated into the peptides linking the heterodimerizing coiled coils and the GFP fragments, such that when cleaved by caspase- 3 , the two parts become uncaged and free to bind. The researchers injected mRNA encoding ZipGFP into live zebrafish to visualize caspase activity and apoptosis of the vertebrate in vivo. They found that the spatial pattern of ZipGFP fluorescence at 2 days post fertilization was consistent with a previous study based on terminal deoxynucleotidyl transferase dUTP nick end labeling (TUNEL) staining and further showed that apoptosis first occurred at the rostral part of the forebrain before appearing in other parts of the brain and the trunk, a finding that would have been extremely difficult to observe with the limited spatial resolution of TUNEL staining using fixed samples. The design of ZipGFP will likely be used to create reporters of many other proteases, allowing us to study protease dynamics with unprecedented spatiotemporal resolution.

\section{Emerging optogenetic technologies}

The investigation of dynamic developmental processes requires fast and flexible methods to perturb protein function. The classic method to perturb protein function in zebrafish embryos is simply to add drugs to the swimming media. Since zebrafish embryos are small, many small molecules are able to penetrate even deep tissues. However, drugs delivered this way diffuse to all tissues, not only to cells and tissues of interest. With the advance of zebrafish genetics, proteins can be more finely regulated both spatially and temporally at the transcription level. Tissue-level spatial resolution of expression or recombination is often achieved by the use of cell type-specific promoters, whereas temporal control is achieved via the administration of small-molecule compounds, such as in the LexPR ${ }^{113}$, TetON, or TetOFF systems ${ }^{114}$, or activation of heat shock promoters ${ }^{115,116}$. Photoactivatable morpholinos and photo-cleavable morpholinos can also be used 
to switch on and off morpholino activity, respectively, using ultraviolet (UV) 365-nm light ${ }^{72,90,117,118}$. However, morpholinos are typically injected into embryos at the one-cell stage and delivered to all cells in the developing embryo, and as such UV irradiation of a specific region of the embryo activates photomorpholinos in all cells of the region, not just in cells of interest. Importantly, the temporal control afforded by photomorpholinos can be applied once only; once you activate a photomorpholino with UV light, you cannot control its deactivation. Recently, novel optogenetic tools based on light-induced protein-protein interactions offered the opportunity to control protein function reversibly down to the subcellular scale, not only at the transcription level but at all stages of a protein's life.

Proteins that interact only with other proteins or protein domains under light conditions are common in organisms that photosynthesize, such as plants, algae, and cyanobacteria (Table 3). The three most well-known photosensitive proteins that have been used for controlling other proteins are cryptochrome2 (CRY2), the light-oxygen-voltage (LOV) domain, and phytochrome B (PhyB). Of these, the most commonly used photosensitive protein is CRY2, which binds to the basic-helix-loop-helix (bHLH) transcription factor CIB1 upon blue light illumination. In cultured cells, association occurs on a subsecond timescale and reversion is a spontaneous process with half-life times occurring within minutes $^{119}$. The CRY2 mutation E490G can also act as an optogenetic system where blue light stimulation induces oligomerization of the protein ${ }^{120}$. The feasibility of creating optogenetic gene switches in zebrafish using the CRY2/CIB1 system was recently confirmed in a proof-of-principle $\operatorname{study}^{121}$ (Figure $3 \mathrm{~A}$ ), although biological applications of the system in zebrafish are still pending.

The second most used system is the LOV domain, which forms a covalent bond with the flavin cofactor and undergoes a conformational change upon blue light stimulation. As with CRY2, the conformational change is spontaneously reversible in the dark. Since its discovery, various LOV domain-derived optogenetic modules have been developed ${ }^{122-126}$. Some of these are based on binding the LOV domain directly to an effector protein and rely on light to uncage the effector protein. Others are based on LOV domain heterodimerization with natural or engineered binding partners in response to light. Still others are based on the ability of LOV domains to homodimerize. A LOV-based Rac1 photouncaging system (Figure 3B) has been used in the zebrafish to study neutrophil motility ${ }^{127}$. The study successfully demonstrated that localized activation of the small GTPase at the leading edge of neutrophils is sufficient to direct their migration with precise temporal and spatial control and that $\mathrm{PI}(3) \mathrm{K}$-mediated regulation of neutrophil motility occurred through both the modulation of Rac-mediated protrusion at the leading edge and anteroposterior polarity of F-actin dynamics ${ }^{127}$. In another study, photoactivatable Nodal receptors based on LOV domain homodimerization were used to study cell fate specification during zebrafish gastrulation ${ }^{128}$. Through these photoactivatable Nodal receptors, the study found that extending Nodal signaling within the zebrafish embryonic organizer induces prechordal plate and suppresses endoderm specification. Most recently, a light-inducible gene expression system based on EL222, a naturally occurring light-responsive transcription factor that contains a LOV domain, was optimized for low toxicity in zebrafish ${ }^{126}$. In the dark, the LOV domain binds to a helix-turn-helix (HTH) DNA-binding domain. Upon irradiation with blue light, the interaction between the LOV domain and the HTH is disrupted, and HTH is free to homodimerize and bind to a regulatory element termed $\mathrm{C} 120$. The authors were able to use the system, named TAEL, to induce ectopic endodermal cells in the presumptive ectoderm via targeted induction of the transcription factor sox32 and modulation of Nodal signaling dynamics by inducing leftyl expression. Furthermore, the authors demonstrated how their LOV-based system can be used together with the latest genome-editing technology, CRISPR/Cas9, to induce gene mutations specifically in cells irradiated by light ${ }^{126}$ (Figure 3C).

Lastly, PhyB binds to its partner PIF3/6, a transcription factor with a helix-loop-helix structure, upon red light stimulation and dissociates with PIF3/6 upon exposure to far-red light. Advantages of this system over CRY2/CIB1 and LOV-based systems include the lower toxicity and deeper penetration of red/far-red light compared

Table 3. Light-inducible protein interaction systems used in zebrafish.

\begin{tabular}{|l|l|l|l|l|l|}
\hline $\begin{array}{l}\text { Photosensitive } \\
\text { protein }\end{array}$ & Mechanism & $\begin{array}{l}\text { Light, } \\
\mathbf{n m}\end{array}$ & $\begin{array}{l}\text { Activation/Inactivation time } \\
\text { in cell culture }\end{array}$ & $\begin{array}{l}\text { Use in } \\
\text { zebrafish }\end{array}$ & References \\
\hline CRY2 & $\begin{array}{l}\text { CRY2/CIB1 } \\
\text { heterodimerization }\end{array}$ & 488 & Seconds/Minutes & 121 & 119 \\
\hline $\begin{array}{l}\text { LOV domain: } \\
\text { AsLOV2 }\end{array}$ & $\begin{array}{l}\text { Unfolding of J } \alpha \\
\text { helix }\end{array}$ & 465 & Seconds/Seconds & 127 & 122,153 \\
\hline $\begin{array}{l}\text { LOV domain: } \\
\text { TAEL-HTH }\end{array}$ & $\begin{array}{l}\text { TAEL-HTH } \\
\text { homodimerization }\end{array}$ & 465 & Seconds/Seconds & 126 & 124 \\
\hline $\begin{array}{l}\text { LOV domain: } \\
\text { AUREO1-LOV }\end{array}$ & $\begin{array}{l}\text { Homodimerization } \\
\text { Hemp }\end{array}$ & 465 & Seconds/Seconds & 128 & 154 \\
\hline PhyB & $\begin{array}{l}\text { PhyB/PIF6 } \\
\text { heterodimerization }\end{array}$ & $633 / 750$ & $\begin{array}{l}\text { Milliseconds/Milliseconds } \\
\text { (inactivation with far-red light) }\end{array}$ & 129,130 & 155,156 \\
\hline
\end{tabular}

${ }^{a}$ Based on parent protein EL222. 
A Optogenetic control of gene expression

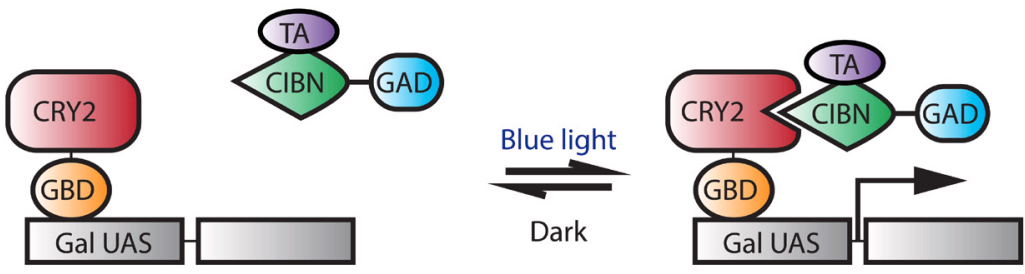

B Photo-uncaging of enzymes

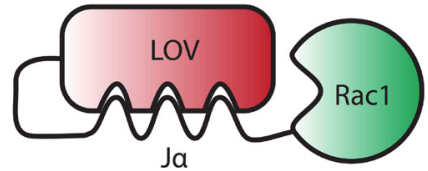

C Optogenetic genome editing

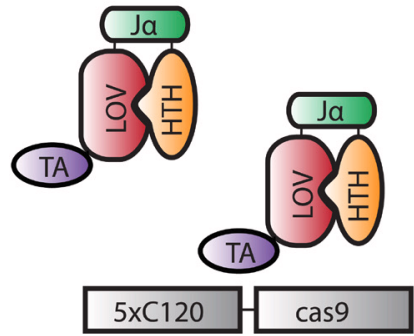

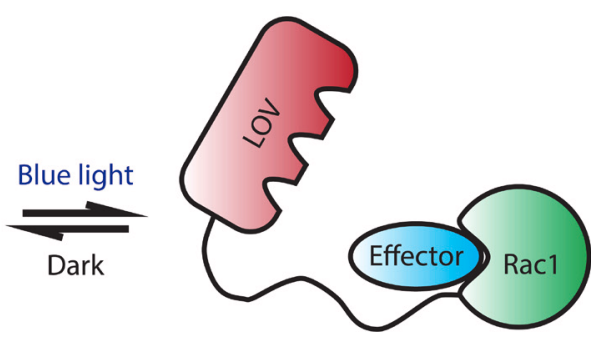

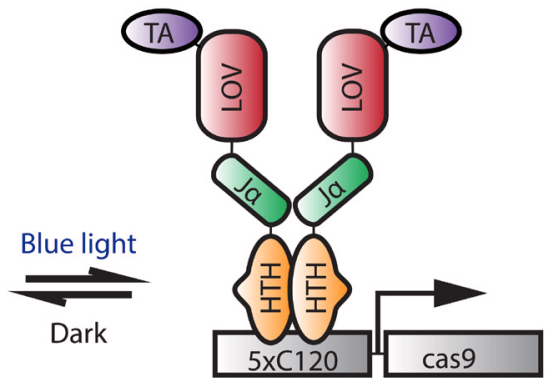

D Optogenetic control of protein localisation

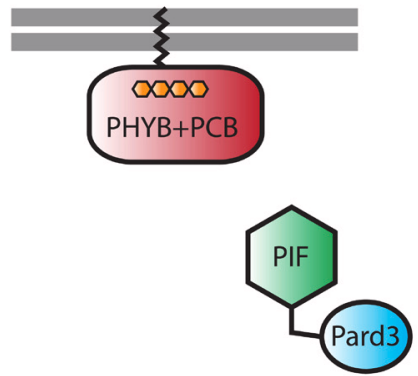

Far red light

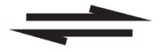

Infra-red light

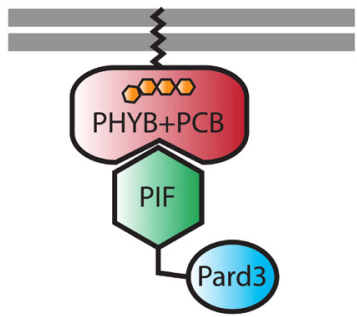

Figure 3. Optogenetic approaches in zebrafish. (A) Optogenetic control of gene expression. In this approach, cryptochrome2 (CRY2) is fused to the Gal4 DNA-binding domain, GBD, and CIBN is fused to a transcription activator (TA) and to GAD, a domain required for transcriptional activation through interaction with transcriptional machinery. In the dark, CRY2 does not associate with CIBN. Upon illumination with blue light, CRY2 binds to CIBN, leading to the expression of the gene of interest. (B) Photo-uncaging of enzymes. This photoactivatable Rac1 consists of a light-oxygen-voltage (LOV) domain connected to a J $\alpha$ helix, which is then fused to Rac1. In the dark, LOV binds to J $\alpha$ and sterically inhibits the interaction of Rac1 with its downstream effectors. Upon blue light illumination, the helix unwinds and frees Rac1, thus restoring its activity. (C) Optogenetic genome editing. Here, the LOV domain is fused to a TA and to a helix-turn-helix (HTH) DNA-binding domain via the J $\alpha$ linker. In the dark, the LOV domain interacts with HTH. Upon illumination with blue light, HTH is released and allowed to dimerize and bind to DNA, leading to the expression of cas9. (D) Optogenetic control of protein localization. In this system, phytochrome $\mathrm{B}$ (PHYB) is tethered to the membrane via the CAAX motif while PIF is fused to Pard3. In the dark, PHYB does not associate with PIF. Upon illumination with far-red light, PHYB undergoes a conformational change, allowing it to bind to PIF, thus recruiting Pard3 to the membrane. The conformational change of PHYB, and hence its interaction with PIF, is reversible upon infra-red light illumination. This system requires the external cofactor phycocyanobilin (PCB). 
with blue light and the greater control of protein activity afforded by the ability to control the OFF state as well as the ON state of the interaction with light. The PhyB/(PIF3/6) system has not been widely used, because it requires a chromophore, phycocyanobilin (PCB), which is not naturally present in many multicellular organisms, including zebrafish. The PhyB/PIF3 system can be applied to the superficial cells of the zebrafish simply by adding PCB to the medium, as has been done by 129 to control the nuclear localization of proteins with red light. A more recent study ${ }^{130}$ was able to apply this system to even deep tissues of the zebrafish by injecting a purified version of PCB into one cell of the embryo at the 16-cell stage along with a truncated version of PhyB that optimizes its expression (Figure 3D). The authors generated a Pard3-PIF6 fusion construct and were able to direct the apical polarity protein Pard 3 and recruit its binding partner Pard6 to specific membrane locations in the neural progenitors using red laser light.

A promising new area in the optogenetics field is the modification of fluorescent proteins for use as optogenetic regulators of protein function, in part because they have the potential advantage of being sensors of their own activity. So far, two fluorescent proteins that have been modified for this purpose are Dronpa, a photoswitchable fluorescent protein, and mMaple, a photoconvertible fluorescent protein. As discussed previously, the fluorescence of Dronpa can be switched off by blue 488-nm light and switched on again by violet 405-nm light exposure. Another property of this protein is that light can be used to change its oligomerization status. In its fluorescent state, Dronpa monomers bind to one another to form dimers and then these dimers come together to form tetramers. Switching off Dronpa fluorescence using blue light converts the protein to monomers, whereas switching on Dronpa fluorescence using violet light reverts the protein to its oligomerized state. Taking advantage of this property, an engineered variant of Dronpa containing a point mutation, which makes the protein less likely to form tetramers in low micromolar concentrations and facilitates offphotoswitching, has been used as an optogenetic module that allows reversible uncaging of the effector $\operatorname{protein}^{131}$ (Figure 4A). To our knowledge, the use of Dronpa for photocaging has not been implemented in zebrafish or other in vivo systems.

The second fluorescent protein that has been used for optogenetics, mMaple, converts from green to red fluorescence upon violet light (about 400-nm) irradiation. Recently, this protein was modified such that violet light irradiation causes irreversible cleavage of the protein as well as loss of green fluorescence ${ }^{132}$

A Dronpa-based optogenetic system

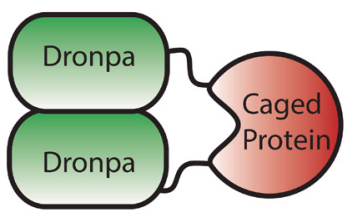

Blue light

Violet light

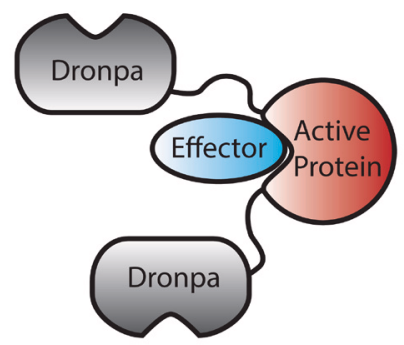

B PhoCl-based optogenetic system
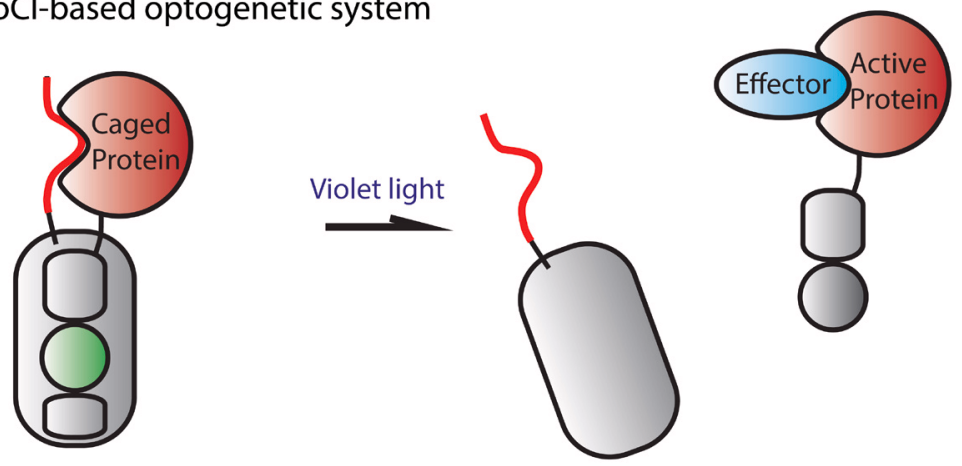

Figure 4. Fluorescent protein-based optogenetic systems. (A) The protein of interest is fused to two Dronpa proteins. Initially, Dronpa is in its "ON" fluorescent state and forms dimers that cause inhibition of protein function by steric interference. Upon irradiation with blue light, the Dronpa dimers dissociate and release protein activity and lose fluorescence. Dronpa can be triggered to form dimers and fluoresce again by irradiation with violet light. (B) The protein of interest is fused to PhoCl, as is a linker that blocks the protein's function. Initially, the protein of interest is caged and $\mathrm{PhoCl}$ fluoresces green light. Irradiation with violet light irreversibly cleaves PhoCl, releasing the protein of interest, and the chromophore's green fluorescence is lost. 
(Figure 4B). This modified version of mMaple, called $\mathrm{PhoCl}$ (photocleavable protein), can be used to cage proteins in an inactive state until release by photocleavage. The use of highenergy violet light to elicit photocleavage can be circumvented by using primed conversion with lower-energy 458-nm and 730-nm light. Importantly, unlike other optogenetic systems, where constant illumination is required to sustain protein activity, once $\mathrm{PhoCl}$ is cleaved, uncaged proteins persist until they are degraded by normal cellular processes. Also, $\mathrm{PhoCl}$ systems have much lower levels of dark-state activity than systems based on photosensitive proteins whose photo-induced conformational change is reversible. $\mathrm{PhoCl}$ systems are thus highly advantageous in scenarios where low levels of protein activity before light irradiation and prolonged protein activity after light irradiation are desired. The inventors of $\mathrm{PhoCl}$ demonstrated its versatility by using the protein to engineer photoactivatable Cre-recombinase, photoactivatable Gal4 transcription factor, and a photoactivatable viral protease. The system has yet to be tested in vivo but, should it work in zebrafish, its unique properties will undoubtedly be valuable to the zebrafish community.

As can be seen from the examples above, optogenetic strategies can be applied to control cell activities as wide ranging as differentiation, migration, and polarization. The versatility of photo-inducible protein-protein interaction systems is such that optogenetics can be used to study almost all areas of developmental and cell biology. That both blue light systems (CRY2/CIBN, LOV) and red/far-red light systems (PHYB/PIF) are workable in zebrafish means that both systems could potentially be used simultaneously. A downside of current zebrafish-tested optogenetic systems is that they are slightly "leaky", in that some photosensitive protein modules expressed in cells exist in the activated state even in the dark. As in the case with fluorescent proteins, the tool kit of photo-inducible protein-protein interaction systems is also expected to expand from the discovery and isolation of new naturally occurring photosensitive proteins from different organisms. These systems will respond to different wavelengths of light and will have different activation/inactivation kinetics as well as different changes in binding affinity between the protein dimers during light and dark states, making them suitable for different applications.

\section{Conclusions and outlook}

We hope that the examples we have provided illustrate how the latest advances in fluorescent protein and optogenetic technologies can be applied to answer important developmental questions in living zebrafish embryos and larvae. Since data obtained from in vitro studies do not always match up to what happens in vivo, zebrafish constitute an increasingly valuable model to study vertebrate biology permitting the powerful use of phototechnologies. The advances described here come at a time when microscopy tools and approaches ${ }^{133-138}$, as well as computational tools for data management and image analysis, are also undergoing rapid development (for some computational tools specific for zebrafish, see 139-142). With the increasing trend of creating microscopes that are optimized for simultaneous optogenetic manipulation and high resolution, long-term imaging remains one of the major goals in the near future. Exciting areas of development will be analyzing and extracting meaningful information from gene expression profiling combined with quantitative information about the cell behaviors and identities in vivo. There is a lot to bet that continual interactions between chemists, biologists, computational scientists, engineers, and physicists will be key to reaching that level of understanding.

\section{Competing interests}

The authors declare that they have no competing interests.

\section{Grant information}

JV and RC are supported by Fondation pour la Recherche Médicale (DEQ20140329553). JV is supported by the Agence Nationale de la Recherche (ANR) (ANR-15-CE13-0015-01 and ANR-12-ISV2-0001-01), the European Molecular Biology Organization Young Investigator Program, European Research Council consolidator grant Evalve (682938), and grant ANR10-LABX-0030-INRT, a French State fund managed by the ANR under the frame program Investissements d'Avenir labeled ANR-10-IDEX-0002-02.

\section{Acknowledgments}

We thank the JV lab for discussions on the manuscript.
1. Laale HW: The biology and use of zebrafish, Brachydanio rerio in fisheries research. Journal of Fish Biology. 1977; 10(2): 121-173. Publisher Full Text

2. Karlsson J, von Hofsten J, Olsson PE: Generating transparent zebrafish: a refined method to improve detection of gene expression during embryonic development. Mar Biotechnol (NY). 2001; 3(6): 522-7. PubMed Abstract | Publisher Full Text

3. Lister JA, Robertson CP, Lepage $\mathrm{T}$, et al:: nacre encodes a zebrafish microphthalmia-related protein that regulates neural-crest-derived pigment cell fate. Development. 1999; 126(17): 3757-67. PubMed Abstract

4. White RM, Zon LI: Melanocytes in development, regeneration, and cancer. Cell Stem Cell. 2008; 3(3): 242-52. PubMed Abstract | Publisher Full Text

5. Lopes SS, Yang X, Müller J, et al.: Leukocyte tyrosine kinase functions in pigment cell development. PLoS Genet. 2008: 4(3): e1000026. PubMed Abstract | Publisher Full Text | Free Full Text

6. Odenthal J, Rossnagel K, Haffter $\mathrm{P}$, et al.: Mutations affecting xanthophore pigmentation in the zebrafish, Danio rerio. Development. 1996; 123: 391-8. PubMed Abstract

7. Antinucci P, Hindges R: A crystal-clear zebrafish for in vivo imaging. Sci Rep. 2016; 6: 29490.

PubMed Abstract | Publisher Full Text | Free Full Text

8. Nüsslein-Volhard C: The zebrafish issue of Development. Development. 2012; 139(22): 4099-103.

PubMed Abstract | Publisher Full Text

9. Kimmel CB, Ballard WW, Kimmel SR, et al:: Stages of embryonic development of the zebrafish. Dev Dyn. 1995; 203(3): 253-310. PubMed Abstract | Publisher Full Text

10. Hammerschmidt M, Blader P, Strahle U: Strategies to perturb zebrafish 
development. Methods Cell Biol. 1999; 59: 87-115. PubMed Abstract | Publisher Full Text

11. F Nasevicius A, Ekker SC: Effective targeted gene 'knockdown' in zebrafish. Nat Genet. 2000; 26(2): 216-20.

PubMed Abstract | Publisher Full Text | F1000 Recommendation

12. Woo K, Shih J, Fraser SE: Fate maps of the zebrafish embryo. Curr Opin Genet Dev. 1995: 5(4): 439-43.

PubMed Abstract | Publisher Full Text

13. O'Malley DM, Zhou Q, Gahtan E: Probing neural circuits in the zebrafish: a suite of optical techniques. Methods. 2003; 30(1): 49-63.

PubMed Abstract | Publisher Full Text

14. Tsien RY: The green fluorescent protein. Annu Rev Biochem. 1998; 67: 509-44. PubMed Abstract | Publisher Full Tex

15. Chalfie M, Tu Y, Euskirchen G, et al.: Green fluorescent protein as a marker for gene expression. Science. 1994; 263(5148): 802-5. PubMed Abstract | Publisher Full Text

16. Amsterdam $\mathrm{A}$, Lin $\mathrm{S}$, Hopkins $\mathrm{N}$ : The Aequorea victoria green fluorescent protein can be used as a reporter in live zebrafish embryos. Dev Biol. 1995; 171(1): 123-9.

PubMed Abstract | Publisher Full Text

17. Lin S: Transgenic zebrafish. Methods Mol Biol. 2000; 136: 375-83. PubMed Abstract | Publisher Full Text

18. Lawson ND, Weinstein BM: In vivo imaging of embryonic vascular development using transgenic zebrafish. Dev Biol. 2002; 248(2): 307-18.

PubMed Abstract | Publisher Full Text

19. Kawakami K, Takeda H, Kawakami N, et al:: A transposon-mediated gene trap approach identifies developmentally regulated genes in zebrafish. Dev Cell. 2004; 7(1): 133-44.

PubMed Abstract | Publisher Full Tex

20. Scott EK, Mason L, Arrenberg AB, et al:: Targeting neural circuitry in zebrafish using GAL4 enhancer trapping. Nat Methods. 2007; 4(4): 323-6.

PubMed Abstract | Publisher Full Text

21. Asakawa K, Suster ML, Mizusawa K, et al:: Genetic dissection of neural circuits by Tol2 transposon-mediated Gal4 gene and enhancer trapping in zebrafish. Proc Natl Acad Sci U S A. 2008; 105(4): 1255-60. PubMed Abstract | Publisher Full Text | Free Full Text

22. Surrey T, Elowitz MB, Wolf PE, et al:: Chromophore-assisted light inactivation and self-organization of microtubules and motors. Proc Natl Acad Sci U S A. 1998; 95(8): 4293-8.

PubMed Abstract | Publisher Full Text | Free Full Text

23. F Boyden ES, Zhang F, Bamberg E, et al.: Millisecond-timescale, genetically targeted optical control of neural activity. Nat Neurosci. 2005; 8(9): 1263-8. PubMed Abstract | Publisher Full Text | F1000 Recommendation

24. Simmich J, Staykov E, Scott E: Zebrafish as an appealing model for optogenetic studies. In, Progress in Brain Research, K. Thomas and S.B. Edward, Editors. Elsevier. 2012; 196: 145-162.

PubMed Abstract | Publisher Full Text

25. Portugues R, Severi KE, Wyart C, et al: Optogenetics in a transparent animal: circuit function in the larval zebrafish. Curr Opin Neurobiol. 2013; 23(1): 119-26. PubMed Abstract | Publisher Full Text

26. Del Bene F, Wyart C: Optogenetics: a new enlightenment age for zebrafish neurobiology. Dev Neurobiol. 2012; 72(3): 404-14.

PubMed Abstract | Publisher Full Text

27. Knafo $S$, Wyart $C$ : Optogenetic neuromodulation: new tools for monitoring and breaking neural circuits. Ann Phys Rehabil Med. 2015; 58(4): 259-64. PubMed Abstract | Publisher Full Text

28. Arrenberg $\mathrm{AB}$, Stainier DY, Baier $\mathrm{H}$, et al:: Optogenetic control of cardiac function. Science. 2010; 330(6006): 971-4. PubMed Abstract | Publisher Full Text

29. Anton $\mathrm{H}$, Harlepp S, Ramspacher $\mathrm{C}$, et al.: Pulse propagation by a capacitive mechanism drives embryonic blood flow. Development. 2013; 140(21): 4426-34. PubMed Abstract | Publisher Full Text

30. F Livet J, Weissman TA, Kang H, et al:: Transgenic strategies for combinatorial expression of fluorescent proteins in the nervous system. Nature. 2007; 450(7166): 56-62.

PubMed Abstract | Publisher Full Text | F1000 Recommendation

31. Pan YA, Livet J, Sanes JR, et al.: Multicolor Brainbow imaging in zebrafish. Cold Spring Harb Protoc. 2011; 2011(1): pdb.prot5546. PubMed Abstract | Publisher Full Text | Free Full Text

32. Pan YA, Freundlich T, Weissman TA, et al:: Zebrabow: multispectral cell labeling for cell tracing and lineage analysis in zebrafish. Development. 2013; 140(13): 2835-46.

PubMed Abstract | Publisher Full Text | Free Full Text

33. Robles E, Filosa A, Baier H: Precise lamination of retinal axons generates multiple parallel input pathways in the tectum. J Neurosci. 2013; 33(11): 5027-39. PubMed Abstract | Publisher Full Text | Free Full Text

34. Gupta V, Poss KD: Clonally dominant cardiomyocytes direct heart morphogenesis. Nature. 2012; 484(7395): 479-84. PubMed Abstract | Publisher Full Text | Free Full Text

35. F Foglia MJ, Cao J, Tornini VA, et al:: Multicolor mapping of the cardiomyocyte proliferation dynamics that construct the atrium. Development.
2016; 143(10): 1688-96.

PubMed Abstract | Publisher Full Text | Free Full Text | F1000 Recommendation

36. F Pestel J, Ramadass R, Gauvrit S, et al:: Real-time 3D visualization of cellular rearrangements during cardiac valve formation. Development. 2016; 143(12): 2217-27.

PubMed Abstract | Publisher Full Text | Free Full Text | F1000 Recommendation

37. $\mathrm{F}$ Chen $\mathrm{CH}$, Puliafito $\mathrm{A}, \mathrm{Cox} \mathrm{BD}$, et al:: Multicolor Cell Barcoding Technology or Long-Term Surveillance of Epithelial Regeneration in Zebrafish. Dev Cell. 2016; 36(6): 668-80.

PubMed Abstract | Publisher Full Text | Free Full Text | F1000 Recommendation

38. Xiong F, Obholzer ND, Noche RR, et al:: Multibow: digital spectral barcodes for cell tracing. PLoS One. 2015; 10(5): e0127822.

PubMed Abstract | Publisher Full Text | Free Full Text

39. F Huisken J, Swoger J, Del Bene F, et al:: Optical sectioning deep inside live embryos by selective plane illumination microscopy. Science. 2004; 305(5686): 1007-9.

PubMed Abstract | Publisher Full Text | F1000 Recommendation

40. F Keller PJ, Schmidt AD, Wittbrodt J, et al.: Reconstruction of zebrafish early embryonic development by scanned light sheet microscopy. Science. 2008; 322(5904): 1065-9.

PubMed Abstract | Publisher Full Text | F1000 Recommendation

41. $\mathrm{F}$ Mahou $\mathrm{P}$, Zimmerley M, Loulier $\mathrm{K}$, et al:: Multicolor two-photon tissue imaging by wavelength mixing. Nat Methods. 2012; 9(8): 815-8. PubMed Abstract | Publisher Full Text | F1000 Recommendation

42. $\mathrm{F}$ Ando $\mathrm{R}$, Hama $\mathrm{H}$, Yamamoto-Hino $\mathrm{M}$, et al:: An optical marker based on the UV-induced green-to-red photoconversion of a fluorescent protein. Proc Natl Acad Sci U S A. 2002; 99(20): 12651-6.

PubMed Abstract | Publisher Full Text | Free Full Text | F1000 Recommendation

43. F Patterson GH, Lippincott-Schwartz J: A photoactivatable GFP for selective photolabeling of proteins and cells. Science. 2002; 297(5588): 1873-7. PubMed Abstract | Publisher Full Text | F1000 Recommendation

44. Habuchi S, Ando R, Dedecker P, et al:: Reversible single-molecule photoswitching in the GFP-like fluorescent protein Dronpa. Proc Natl Acad Sci U S A. 2005; 102(27): 9511-6.

PubMed Abstract | Publisher Full Text | Free Full Text

45. Nienhaus K, Nienhaus GU: Fluorescent proteins for live-cell imaging with super-resolution. Chem Soc Rev. 2014; 43(4): 1088-106. PubMed Abstract | Publisher Full Text

46. Aramaki S, Hatta K: Visualizing neurons one-by-one in vivo: optical dissection and reconstruction of neural networks with reversible fluorescent proteins. Dev Dyn. 2006; 235(8): 2192-9. PubMed Abstract | Publisher Full Tex

47. Sato T, Takahoko M, Okamoto H: HuC:Kaede, a useful tool to label neural morphologies in networks in vivo. Genesis. 2006; 44(3): 136-42. PubMed Abstract | Publisher Full Text

48. Beretta CA, Dross N, Bankhead P, et al:: The ventral habenulae of zebrafish develop in prosomere 2 dependent on Tcf7l2 function. Neural Dev. 2013; 8: 19 PubMed Abstract | Publisher Full Text | Free Full Text

49. Steed E, Faggianelli N, Roth S, et al.: klf2a couples mechanotransduction and zebrafish valve morphogenesis through fibronectin synthesis. Nat Commun. 2016; 7: 11646.

PubMed Abstract | Publisher Full Text | Free Full Text

50. Yoo SK, Huttenlocher A: Spatiotemporal photolabeling of neutrophil trafficking during inflammation in live zebrafish. J Leukoc Biol. 2011; 89(5): 661-7. PubMed Abstract | Publisher Full Text | Free Full Text

51. Dempsey WP, Fraser SE, Pantazis P: PhOTO zebrafish: a transgenic resource for in vivo lineage tracing during development and regeneration. PLOS One. 2012; 7(3): e32888.

PubMed Abstract | Publisher Full Text | Free Full Text

52. He J, Zhang G, Almeida AD, et al:: How variable clones build an invariant retina. Neuron. 2012; 75(5): 786-98.

PubMed Abstract | Publisher Full Text | Free Full Text

53. Bianco $\mathrm{IH}, \mathrm{Ma} \mathrm{LH}$, Schoppik $\mathrm{D}$, et al:: The tangential nucleus controls a gravitoinertial vestibulo-ocular reflex. Curr Biol. 2012; 22(14): 1285-95. PubMed Abstract | Publisher Full Text | Free Full Text

54. Mohr MA, Argast P, Pantazis $P$ : Labeling cellular structures in vivo using confined primed conversion of photoconvertible fluorescent proteins. Nat Protoc. 2016; 11(12): 2419-31. PubMed Abstract | Publisher Full Tex

55. F Brown SC, Bolte S, Gaudin M, et al:: Exploring plant endomembrane dynamics using the photoconvertible protein Kaede. Plant J. 2010; 63(4): 696-711.

PubMed Abstract | Publisher Full Text | F1000 Recommendation

56. F Dempsey WP, Georgieva L, Helbling PM, et al.: in vivo single-cell labeling by confined primed conversion. Nat Methods. 2015; 12(7): 645-8. PubMed Abstract | Publisher Full Text | F1000 Recommendation

57. Klementieva NV, Lukyanov KA, Markina NM, et al:: Green-to-red primed conversion of Dendra2 using blue and red lasers. Chem Commun (Camb). 2016 52(89): 13144-6.

PubMed Abstract | Publisher Full Text 
58. Subach OM, Patterson GH, Ting LM, et al.: A photoswitchable orange-to-far-red fluorescent protein, PSmOrange. Nat Methods. 2011; 8(9): 771-7. PubMed Abstract | Publisher Full Text | Free Full Text

59. Subach OM, Entenberg D, Condeelis JS, et al.: A FRET-facilitated photoswitching using an orange fluorescent protein with the fast photoconversion kinetics. J Am Chem Soc. 2012; 134(36): 14789-99. PubMed Abstract | Publisher Full Text | Free Full Text

60. F Nicenboim J, Malkinson G, Lupo T, et al:: Lymphatic vessels arise from specialized angioblasts within a venous niche. Nature. 2015; 522(7554): 56-61. PubMed Abstract | Publisher Full Text | F1000 Recommendation

61. F Chen TW, Wardill TJ, Sun Y, et al.: Ultrasensitive fluorescent proteins for imaging neuronal activity. Nature. 2013; 499(7458): 295-300. PubMed Abstract | Publisher Full Text | Free Full Text | F1000 Recommendation

62. Helassa N, Podor B, Fine A, et al.: Design and mechanistic insight into ultrafast calcium indicators for monitoring intracellular calcium dynamics. Sci Rep. 2016; 6: 38276 .

PubMed Abstract | Publisher Full Text | Free Full Text

63. Lin MZ, Schnitzer MJ: Genetically encoded indicators of neuronal activity. Nat Neurosci. 2016; 19(9): 1142-53. PubMed Abstract | Publisher Full Text

64. F Higashijima S, Masino MA, Mandel G, et al:: Imaging neuronal activity during zebrafish behavior with a genetically encoded calcium indicator. J Neurophysiol. 2003; 90(6): 3986-97.

PubMed Abstract | Publisher Full Text | F1000 Recommendation

65. F Dunn TW, Mu Y, Narayan S, et al:: Brain-wide mapping of neural activity controlling zebrafish exploratory locomotion. eLife. 2016; 5: e12741. PubMed Abstract | Publisher Full Text | Free Full Text | F1000 Recommendation

66. Ahrens MB, Orger MB, Robson DN, et al.: Whole-brain functional imaging at cellular resolution using light-sheet microscopy. Nat Methods. 2013; 10(5): 413-20.

PubMed Abstract | Publisher Full Text

67. Vladimirov $\mathrm{N}, \mathrm{Mu} \mathrm{Y}, \mathrm{Kawashima} \mathrm{T}$, et al.: Light-sheet functional imaging in fictively behaving zebrafish. Nat Methods. 2014; 11(9): 883-4. PubMed Abstract | Publisher Full Text

68. F Chhetri RK, Amat F, Wan $\mathrm{Y}$, et al.: Whole-animal functional and developmental imaging with isotropic spatial resolution. Nat Methods. 2015 12(12): 1171-8.

PubMed Abstract | Publisher Full Text | F1000 Recommendation

69. F Wolf $\mathrm{S}$, Supatto W, Debrégeas $\mathrm{G}$, et al.: Whole-brain functional imaging with two-photon light-sheet microscopy. Nat Methods. 2015; 12(5): 379-80. PubMed Abstract | Publisher Full Text | F1000 Recommendation

70. Chi NC, Shaw RM, Jungblut B, et al:: Genetic and physiologic dissection of the vertebrate cardiac conduction system. PLOS Biol. 2008; 6(5): e109. PubMed Abstract | Publisher Full Text | Free Full Text

71. Ramspacher C, Steed E, Boselli F, et al.: Developmental Alterations in Heart Biomechanics and Skeletal Muscle Function in Desmin Mutants Suggest an Early Pathological Root for Desminopathies. Cell Rep. 2015; 11(10): 1564-76. PubMed Abstract | Publisher Full Text

72. Goetz JG, Steed E, Ferreira RR, et al: Endothelial cilia mediate low flow sensing during zebrafish vascular development. Cell Rep. 2014; 6(5): 799-808. PubMed Abstract | Publisher Full Text

73. $\mathrm{F}$ Yokota $\mathrm{Y}$, Nakajima $\mathrm{H}$, Wakayama $\mathrm{Y}$, et al.: Endothelial $\mathrm{Ca}^{2+}$ oscillations reflect VEGFR signaling-regulated angiogenic capacity in vivo. eLife. 2015; 4 pii: e08817.

PubMed Abstract | Publisher Full Text | Free Full Text | F1000 Recommendation

74. Dreosti E, Odermatt B, Dorostkar MM, et al.: A genetically encoded reporter of synaptic activity in vivo. Nat Methods. 2009; 6(12): 883-9. PubMed Abstract | Publisher Full Text | Free Full Text

75. Beerman RW, Matty MA, Au GG, et al.: Direct In Vivo Manipulation and Imaging of Calcium Transients in Neutrophils Identify a Critical Role for Leading-Edge Calcium Flux. Cell Rep. 2015; 13(10): 2107-17.

PubMed Abstract | Publisher Full Text | Free Full Text

76. Mizuno H, Sassa T, Higashijima S, et al:: Transgenic zebrafish for ratiometric imaging of cytosolic and mitochondrial $\mathrm{Ca}^{2+}$ response in teleost embryo. Cell Calcium. 2013; 54(3): 236-45.

PubMed Abstract | Publisher Full Text

77. F Yuan S, Zhao L, Brueckner M, et al: Intraciliary calcium oscillations initiate vertebrate left-right asymmetry. Curr Biol. 2015; 25(5): 556-67.

PubMed Abstract | Publisher Full Text | Free Full Text | F1000 Recommendation

78. F Dana H, Mohar B, Sun $\mathrm{Y}$, et al:: Sensitive red protein calcium indicators for imaging neural activity. eLife. 2016; 5: pii: e12727.

PubMed Abstract | Publisher Full Text | Free Full Text | F1000 Recommendation

79. Inoue M, Takeuchi A, Horigane S, et al:: Rational design of a high-affinity, fast red calcium indicator R-CaMP2. Nat Methods. 2015; 12(1): 64-70. PubMed Abstract | Publisher Full Text

80. Akerboom J, Carreras Calderón N, Tian L, et al:: Genetically encoded calcium indicators for multi-color neural activity imaging and combination with optogenetics. Front Mol Neurosci. 2013; 6: 2. PubMed Abstract | Publisher Full Text | Free Full Text

81. Wu J, Liu L, Matsuda T, et al.: Improved orange and red $\mathrm{Ca}^{2+}$ indicators and photophysical considerations for optogenetic applications. ACS Chem Neurosci. 2013; 4(6): 963-72.

PubMed Abstract | Publisher Full Text | Free Full Text

82. Matsuda T, Horikawa $\mathrm{K}$, Saito $\mathrm{K}$, et al:: Highlighted $\mathrm{Ca}^{2+}$ imaging with a genetically encoded 'caged' indicator. Sci Rep. 2013; 3: 1398. PubMed Abstract | Publisher Full Text | Free Full Text

83. Berlin S, Carroll EC, Newman ZL, et al:: Photoactivatable genetically encoded calcium indicators for targeted neuronal imaging. Nat Methods. 2015; 12(9): 852-8.

PubMed Abstract | Publisher Full Text | Free Full Text

84. Sattarzadeh A, Saberianfar R, Zipfel WR, et al:: Green to red photoconversion of GFP for protein tracking in vivo. Sci Rep. 2015; 5: 11771. PubMed Abstract | Publisher Full Text | Free Full Text

85. Hoi H, Matsuda T, Nagai T, et al:: Highlightable $\mathbf{C a}^{2+}$ indicators for live cell imaging. J Am Chem Soc. 2013; 135(1): 46-9.

PubMed Abstract | Publisher Full Text

86. F Fosque BF, Sun $\mathrm{Y}$, Dana $\mathrm{H}$, et al:: Neural circuits. Labeling of active neura circuits in vivo with designed calcium integrators. Science. 2015; 347(6223): 755-60.

PubMed Abstract | Publisher Full Text | F1000 Recommendation

87. Takeda S, Funakoshi T, Hirokawa N: Tubulin dynamics in neuronal axons of living zebrafish embryos. Neuron. 1995; 14(6): 1257-64.

PubMed Abstract | Publisher Full Text

88. F Müller P, Rogers KW, Jordan BM, et al.: Differential diffusivity of Nodal and Lefty underlies a reaction-diffusion patterning system. Science. 2012; 336(6082): 721-4

PubMed Abstract | Publisher Full Text | Free Full Text | F1000 Recommendation

89. Bajanca F, Gonzalez-Perez V, Gillespie SJ, et al:: In vivo dynamics of skeletal muscle Dystrophin in zebrafish embryos revealed by improved FRAP analysis. eLife. 2015; 4: e06541.

PubMed Abstract | Publisher Full Text | Free Full Text

90. Yoo SK, Pascoe HG, Pereira T, et al.: Plexins function in epithelial repair in both Drosophila and zebrafish. Nat Commun. 2016; 7: 12282. PubMed Abstract | Publisher Full Text | Free Full Text

91. Perez-Camps M, Tian J, Chng SC, et al:: Quantitative imaging reveals real-time Pou5f3-Nanog complexes driving dorsoventral mesendoderm patterning in zebrafish. ELife. 2016; 5: pii: e11475.

PubMed Abstract | Publisher Full Text | Free Full Text

92. F Middel V, Zhou L, Takamiya M, et al:: Dysferlin-mediated phosphatidylserine sorting engages macrophages in sarcolemma repair. Nat Commun. 2016; 7 12875.

PubMed Abstract | Publisher Full Text | Free Full Text | F1000 Recommendation

93. Sztal TE, Zhao M, Williams C, et al.: Zebrafish models for nemaline myopathy reveal a spectrum of nemaline bodies contributing to reduced muscle function. Acta Neuropathol. 2015; 130(3): 389-406.

PubMed Abstract | Publisher Full Text | Free Full Text

94. $\mathrm{Ng} \mathrm{XW}$, Teh C, Korzh V, et al:: The Secreted Signaling Protein Wnt3 Is Associated with Membrane Domains In Vivo: A SPIM-FCS Study. Biophys J. 2016; 111(2): 418-29.

PubMed Abstract | Publisher Full Text | Free Full Text

95. Pan $\mathrm{X}, \mathrm{Yu} \mathrm{H}$, Shi $\mathrm{X}$, et al.: Characterization of flow direction in microchannels and zebrafish blood vessels by scanning fluorescence correlation spectroscopy. J Biomed Opt. 2007; 12(1): 014034.

PubMed Abstract | Publisher Full Text

96. F Yu SR, Burkhardt M, Nowak M, et al:: Fgf8 morphogen gradient forms by a source-sink mechanism with freely diffusing molecules. Nature. 2009; 461(7263): 533-6.

PubMed Abstract | Publisher Full Text | F1000 Recommendation

97. Shi X, Teo LS, Pan X, et al.: Probing events with single molecule sensitivity in zebrafish and Drosophila embryos by fluorescence correlation spectroscopy. Dev Dyn. 2009; 238(12): 3156-67.

PubMed Abstract | Publisher Full Text

98. F Shi X, Foo YH, Sudhaharan T, et al:: Determination of dissociation constants in living zebrafish embryos with single wavelength fluorescence cross-correlation spectroscopy. Biophys J. 2009; 97(2): 678-86.

PubMed Abstract | Publisher Full Text | Free Full Text | F1000 Recommendation

99. Khmelinskii A, Knop M: Analysis of protein dynamics with tandem fluorescent protein timers. Methods Mol Biol. 2014; 1174: 195-210.

PubMed Abstract | Publisher Full Text

100. Terskikh A, Fradkov A, Ermakova G, et al:: "Fluorescent timer": protein that changes color with time. Science. 2000; 290(5496): 1585-8.

PubMed Abstract | Publisher Full Text

101. Subach FV, Subach OM, Gundorov IS, et al:: Monomeric fluorescent timers that change color from blue to red report on cellular trafficking. Nat Chem Biol. 2009; 5(2): 118-26.

PubMed Abstract | Publisher Full Text | Free Full Text

102. Tsuboi T, Kitaguchi T, Karasawa S, et al:: Age-dependent preferential densecore vesicle exocytosis in neuroendocrine cells revealed by newly developed monomeric fluorescent timer protein. Mol Biol Cell. 2010; 21(1): 87-94. PubMed Abstract | Publisher Full Text | Free Full Text

103. F Khmelinskii A, Keller PJ, Bartosik A, et al.: Tandem fluorescent protein timers 
for in vivo analysis of protein dynamics. Nat Biotechnol. 2012; 30(7): 708-14. PubMed Abstract | Publisher Full Text | F1000 Recommendation

104. F Donà E, Barry JD, Valentin G, et al.: Directional tissue migration through a self-generated chemokine gradient. Nature. 2013; 503(7475): 285-9. PubMed Abstract | Publisher Full Text | F1000 Recommendation

105. Revenu C, Streichan S, Donà E, et al.: Quantitative cell polarity imaging defines leader-to-follower transitions during collective migration and the key role of microtubule-dependent adherens junction formation. Development. 2014 141(6): 1282-91

PubMed Abstract | Publisher Full Tex

106. F Meyen D, Tarbashevich K, Banisch TU, et al:: Dynamic filopodia are required for chemokine-dependent intracellular polarization during guided cell migration in vivo. ELife. 2015; 4: e05279.

PubMed Abstract | Publisher Full Text | Free Full Text | F1000 Recommendation

107. Cherian AV, Fukuda R, Augustine SM, et al:: N-cadherin relocalization during cardiac trabeculation. Proc Natl Acad Sci U S A. 2016; 113(27): 7569-74. PubMed Abstract | Publisher Full Text | Free Full Text

108. F McMillen P, Chatti V, Jülich D, et al:: A Sawtooth Pattern of Cadherin 2 Stability Mechanically Regulates Somite Morphogenesis. Curr Biol. 2016; 26(4): 542-9.

PubMed Abstract | Publisher Full Text | Free Full Text | F1000 Recommendation

109. Khmelinskii A, Meurer M, Ho CT, et al.: Incomplete proteasomal degradation of green fluorescent proteins in the context of tandem fluorescent protein timers. Mol Biol Cell. 2016; 27(2): 360-70. PubMed Abstract | Publisher Full Text | Free Full Text

110. Barry JD, Donà E, Gilmour D, et al.: TimerQuant: a modelling approach to tandem fluorescent timer design and data interpretation for measuring protein turnover in embryos. Development. 2016; 143(1): 174-9. PubMed Abstract | Publisher Full Text | Free Full Text

111. F To TL, Schepis A, Ruiz-González R, et al:: Rational Design of a GFP-Based Fluorogenic Caspase Reporter for Imaging Apoptosis In Vivo. Cell Chem Biol. 2016; 23(7): 875-82.

PubMed Abstract | Publisher Full Text | Free Full Text | F1000 Recommendation

112. F Cabantous S, Terwilliger TC, Waldo GS: Protein tagging and detection with engineered self-assembling fragments of green fluorescent protein. Nat Biotechnol. 2005: 23(1): 102-7.

PubMed Abstract | Publisher Full Text | F1000 Recommendation

113. Emelyanov A, Parinov S: Mifepristone-inducible LexPR system to drive and control gene expression in transgenic zebrafish. Dev Biol. 2008; 320(1): 113-21. PubMed Abstract | Publisher Full Text

114. F Knopf F, Schnabel K, Haase C, et al.: Dually inducible TetON systems for tissue-specific conditional gene expression in zebrafish. Proc Natl Acad Sci U S A. 2010; 107(46): 19933-8.

PubMed Abstract | Publisher Full Text | Free Full Text | F1000 Recommendation

115. Shoji W, Sato-Maeda M: Application of heat shock promoter in transgenic zebrafish. Dev Growth Differ. 2008; 50(6): 401-6.

PubMed Abstract | Publisher Full Text

116. F Hesselson D, Anderson RM, Beinat M, et al.: Distinct populations of quiescent and proliferative pancreatic beta-cells identified by HOTcre mediated labeling. Proc Natl Acad Sci U S A. 2009; 106(35): 14896-901. PubMed Abstract | Publisher Full Text | Free Full Text | F1000 Recommendation

117. Blum M, de Robertis EM, Wallingford JB, et al:: Morpholinos: Antisense and Sensibility. Dev Cell. 2015; 35(2): 145-9.

PubMed Abstract | Publisher Full Tex

118. F Hamm MJ, Kirchmaier BC, Herzog W: Sema3d controls collective endothelial cell migration by distinct mechanisms via Nrp1 and PIxnD1. J Cell Biol. 2016; 215(3): 415-30

PubMed Abstract | Publisher Full Text | Free Full Text | F1000 Recommendation

119. F Liu H, Yu X, Li K, et al.: Photoexcited CRY2 interacts with CIB1 to regulate transcription and floral initiation in Arabidopsis. Science. 2008; 322(5907): $1535-9$

PubMed Abstract | Publisher Full Text | F1000 Recommendation

120. Taslimi A, Vrana JD, Chen D, et al.: An optimized optogenetic clustering tool for probing protein interaction and function. Nat Commun. 2014; 5: 4925. PubMed Abstract | Publisher Full Text | Free Full Text

121. Liu H, Gomez G, Lin S, et al:: Optogenetic control of transcription in zebrafish PLoS One. 2012; 7(11): e50738.

PubMed Abstract | Publisher Full Text | Free Full Text

122. F Wu YI, Frey D, Lungu OI, et al.: A genetically encoded photoactivatable Rac controls the motility of living cells. Nature. 2009; 461(7260): 104-8. PubMed Abstract | Publisher Full Text | Free Full Text | F1000 Recommendation

123. Polstein LR, Gersbach CA: Light-inducible spatiotemporal control of gene activation by customizable zinc finger transcription factors. J Am Chem Soc. 2012; 134(40): 16480-3.

PubMed Abstract | Publisher Full Text | Free Full Text

124. Motta-Mena LB, Reade A, Mallory MJ, et al:: An optogenetic gene expression system with rapid activation and deactivation kinetics. Nat Chem Biol. 2014 10(3): 196-202.

PubMed Abstract | Publisher Full Text | Free Full Text

125. Guntas G, Hallett RA, Zimmerman SP, et al.: Engineering an improved lightinduced dimer (iLID) for controlling the localization and activity of signaling proteins. Proc Natl Acad Sci U S A. 2015; 112(1): 112-7.

PubMed Abstract | Publisher Full Text | Free Full Text

126. Reade A, Motta-Mena LB, Gardner KH, et al: TAEL: a zebrafish-optimized optogenetic gene expression system with fine spatial and temporal control. Development. 2017; 144(2): 345-55.

PubMed Abstract | Publisher Full Tex

127. F Yoo SK, Deng Q, Cavnar PJ, et al:: Differential regulation of protrusion and polarity by PI3K during neutrophil motility in live zebrafish. Dev Cell. 2010; 18(2): 226-36.

PubMed Abstract | Publisher Full Text | Free Full Text | F1000 Recommendation

128. F Sako K, Pradhan SJ, Barone V, et al.: Optogenetic Control of Nodal Signaling Reveals a Temporal Pattern of Nodal Signaling Regulating Cell Fate Specification during Gastrulation. Cell Rep. 2016; 16(3): 866-77. PubMed Abstract | Publisher Full Text | F1000 Recommendation

129. Beyer HM, Juillot S, Herbst K, et al.: Red Light-Regulated Reversible Nuclea Localization of Proteins in Mammalian Cells and Zebrafish. ACS Synth Biol. 2015; 4(9): 951-8

PubMed Abstract | Publisher Full Text

130. F Buckley CE, Moore RE, Reade A, et al:: Reversible Optogenetic Control of Subcellular Protein Localization in a Live Vertebrate Embryo. Dev Cell. 2016; 36(1): 117-26

PubMed Abstract | Publisher Full Text | Free Full Text | F1000 Recommendation

131. F Zhou XX, Chung HK, Lam AJ, et al.: Optical control of protein activity by fluorescent protein domains. Science. 2012; 338(6108): 810-4. PubMed Abstract | Publisher Full Text | Free Full Text | F1000 Recommendation

132. F Zhang W, Lohman AW, Zhuravlova $Y$, et al:: Optogenetic control with a photocleavable protein, PhoCl. Nat Methods. 2017; 14(4): 391-394. PubMed Abstract | Publisher Full Text | F1000 Recommendation

133. Supatto W, Truong TV, Débarre D, et al.: Advances in multiphoton microscopy for imaging embryos. Curr Opin Genet Dev. 2011; 21(5): 538-48. PubMed Abstract | Publisher Full Text | Free Full Text

134. Pantazis $P$, Supatto $W$ : Advances in whole-embryo imaging: a quantitative transition is underway. Nat Rev Mol Cell Biol. 2014; 15(5): 327-39. PubMed Abstract | Publisher Full Text

135. Follain G, Mercier L, Osmani N, et al:: Seeing is believing - multi-scale spatiotemporal imaging towards in vivo cell biology. J Cell Sci. 2017; 130(1): 23-38. PubMed Abstract | Publisher Full Text

136. Liu Z, Keller PJ: Emerging Imaging and Genomic Tools for Developmenta Systems Biology. Dev Cell. 2016; 36(6): 597-610. PubMed Abstract | Publisher Full Text

137. Stuurman N, Vale RD: Impact of New Camera Technologies on Discoveries in Cell Biology. Biol Bull. 2016; 231(1): 5-13. PubMed Abstract | Publisher Full Text | Free Full Text

138. Huisken J, Stainier DY: Selective plane illumination microscopy techniques in developmental biology. Development. 2009; 136(12): 1963-75. PubMed Abstract | Publisher Full Text | Free Full Text

139. Mikut R, Dickmeis $\mathrm{T}$, Driever W, et al.: Automated processing of zebrafish imaging data: a survey. Zebrafish. 2013; 10(3): 401-21. PubMed Abstract | Publisher Full Text | Free Full Text

140. Ronneberger O, Liu K, Rath M, et al.: ViBE-Z: a framework for 3D virtual colocalization analysis in zebrafish larval brains. Nat Methods. 2012; 9(7): $735-42$. PubMed Abstract | Publisher Full Tex

141. F Randlett $O$, Wee $C L$, Naumann EA, et al:: Whole-brain activity mapping onto a zebrafish brain atlas. Nat Methods. 2015; 12(11): 1039-46. PubMed Abstract | Publisher Full Text | Free Full Text | F1000 Recommendation

142. Eames BF, DeLaurier A, Ullmann B, et al.: FishFace: interactive atlas of zebrafish craniofacial development at cellular resolution. BMC Dev Biol. 2013; 13: 23. PubMed Abstract | Publisher Full Text | Free Full Text

143. Hatta K, Tsujii H, Omura T: Cell tracking using a photoconvertible fluorescent protein. Nat Protoc. 2006; 1(2): 960-7. PubMed Abstract | Publisher Full Text

144. Tsutsui $\mathrm{H}$, Karasawa $\mathrm{S}$, Shimizu $\mathrm{H}$, et al.: Semi-rational engineering of a coral fluorescent protein into an efficient highlighter. EMBO Rep. 2005; 6(3): 233-8. PubMed Abstract | Publisher Full Text | Free Full Text

145. Habuchi S, Tsutsui $\mathrm{H}$, Kochaniak AB, et al:: mKikGR, a monomeric photoswitchable fluorescent protein. PLoS One. 2008; 3(12): e3944. PubMed Abstract |Publisher Full Text | Free Full Text

146. Nakayama S, Ikenaga T, Kawakami K, et al:: Transgenic line with gal4 insertion useful to study morphogenesis of craniofacial perichondrium, vascular endothelium-associated cells, floor plate, and dorsal midline radial glia during zebrafish development. Dev Growth Differ. 2012; 54(2): 202-15. PubMed Abstract | Publisher Full Text | Free Full Text

147. F Masselink W, Cole NJ, Fenyes F, et al:: A somitic contribution to the apical ctodermal ridge is essential for fin formation. Nature. 2016; 535(7613): 542-6. PubMed Abstract | Publisher Full Text | F1000 Recommendation

148. F Wiedenmann J, Ivanchenko S, Oswald F, et al.: EosFP, a fluorescent marker protein with UV-inducible green-to-red fluorescence conversion. Proc Natl Acad Sci U S A. 2004; 101(45): 15905-10.

PubMed Abstract | Publisher Full Text | Free Full Text | F1000 Recommendation

149. Zhang $\mathrm{M}$, Chang $\mathrm{H}$, Zhang $\mathrm{Y}$, et al.: Rational design of true monomeric and 
bright photoactivatable fluorescent proteins. Nat Methods. 2012; 9(7): 727-9. PubMed Abstract | Publisher Full Text

150. F Curran K, Lister JA, Kunkel GR, et al.: Interplay between Foxd3 and Mit regulates cell fate plasticity in the zebrafish neural crest. Dev Biol. 2010; 344(1): 107-18.

PubMed Abstract | Publisher Full Text | Free Full Text | F1000 Recommendation

151. Sapède $D$, Dyballa $S$, Pujades $C$ : Cell lineage analysis reveals three different progenitor pools for neurosensory elements in the otic vesicle. J Neurosci. 2012; 32(46): 16424-34.

PubMed Abstract | Publisher Full Text

152. F Gurskaya NG, Verkhusha VV, Shcheglov AS, et al.: Engineering of a monomeric green-to-red photoactivatable fluorescent protein induced by blue light. Nat Biotechnol. 2006; 24(4): 461-5.

PubMed Abstract | Publisher Full Text | F1000 Recommendation
153. Swartz TE, Corchnoy SB, Christie JM, et al.: The photocycle of a flavin-binding domain of the blue light photoreceptor phototropin. J Biol Chem. 2001; 276(39): 36493-500.

PubMed Abstract | Publisher Full Text

154. Toyooka T, Hisatomi O, Takahashi F, et al.: Photoreactions of aureochrome-1. Biophys J. 2011; 100(11): 2801-9. PubMled Abstract | Publisher Full Text | Free Full Text

155. Rockwell NC, Su YS, Lagarias JC: Phytochrome structure and signaling mechanisms. Annu Rev Plant Biol. 2006; 57: 837-58. PubMed Abstract | Publisher Full Text | Free Full Text

156. F Levskaya A, Weiner OD, Lim WA, et al:: Spatiotemporal control of cell signalling using a light-switchable protein interaction. Nature. 2009; 461(7299): 997-1001.

PubMed Abstract | Publisher Full Text | Free Full Text | F1000 Recommendation 


\section{Open Peer Review}

\section{Current Peer Review Status:}

\section{Editorial Note on the Review Process}

Faculty Reviews are review articles written by the prestigious Members of Faculty Opinions. The articles are commissioned and peer reviewed before publication to ensure that the final, published version is comprehensive and accessible. The reviewers who approved the final version are listed with their names and affiliations.

\section{The reviewers who approved this article are:}

\section{Version 1}

\section{Periklis Pantazis}

Department of Biosystems Science and Engineering (D-BSSE), Eidgenössische Technische Hochschule (ETH) Zurich, Basel, Switzerland

\section{Manuel Alexander Mohr}

Department of Biosystems Science and Engineering (D-BSSE), Eidgenössische Technische Hochschule (ETH) Zurich, Basel, Switzerland

Competing Interests: No competing interests were disclosed.

\section{Filippo Del Bene}

- Institut Curie, PSL Research University, INSERM U 934, CNRS UMR3215, Paris, France

Competing Interests: No competing interests were disclosed.

The benefits of publishing with F1000Research:

- Your article is published within days, with no editorial bias

- You can publish traditional articles, null/negative results, case reports, data notes and more

- The peer review process is transparent and collaborative

- Your article is indexed in PubMed after passing peer review

- Dedicated customer support at every stage

For pre-submission enquiries, contact research@f1000.com 